\title{
DE AMERIKAANSCHE FONDSEN AAN DE AMSTERDAMSCHE BEURS.
}

$W_{i j}$ hebben ons bij gelegenheid van ons jongste beurs-overzicht voorbehouden de Amerikaansche fondsen nader te behandelen en wenschen thans aan dat voornemen uitvoering te geven. De ondervinding onlangs opgedaan met de aandeelen Illinois spoorweg geeft, als wij zeiden, wel aanleiding bij dat voor onze kapitalisten zoo belangrijk onderwerp eens opzettelijk stiltestaan.

Herinneren wij voor alles wat in genoemde zaak is voorgevallen. Het halfjaarlijksche dividend op de aandeelen, dat geruimen tijd geregeld 5 pet. bedroeg, daalde eerst tot 4 pet. en laatstelijk tot 2 pct., en de directie der maatschappij heeft er prijs op gesteld, dat men niet zoude meenen slechts te doen te hebben met uit den aard der zaak voorbijgaande resultaten van eene algemcene lusteloosheid in de handelsbeweging; zij heeft er uitdrukkelijk op gewezen, dat men het nadeel ondervindt van veranderde omstandig. heden, waarin de spoorweg gebracht is door in het algemeen gewijzigde spoorweg-toestanden. Door de uitbreiding der spoorwegen in Illinois is het raijon van het land, waaruit de voor den uitvoer bestemde producten naar deze lijn gebracht worden, zeer ingekrompen; en daar, waar de maatschappij onder normale omstandigheden nog met goed gevolg zoude kunnen concurreeren, is dit voor het oogenblik onmogelijk, omdat, bij de tegenwoordige ongenoegzaamheid van het verkeer ter berrediging van alle concurrenten, ze ten achter staat bij verschillende dezer, vooral bij eenige maatschappijen, die aan hunne verplichtingen niet hebben kunnen voldoen en onder "receivers" beheer zijn gebracht, waardoor ze voorshands voor geen aandeelhouders, zelfs voor geen obligatiehouders te zorgen hebben. Daarbij is nog gekomen, dat de maatschappij ook den invloed ondervonden heeft van den bekenden spoorwegoorlog, eenige maanden lang door vier groote oostelijke spoorwegmaatschappijen gevoerd èn onderling èn tegen de scheepvaart, EcoN. 1877. 
met welke de Illinois spwegmij in verbinding staat. Fen gewichtig besluit zal nu genomen moeten worden ten opzichte der gedragslijn, in het beheer dezer spoorwegzaak te volgen; de vraag moet beslist worden, of men met de bestaande inrichting, zoo goed als mogelijk, zal blijven worstelen tegen de concurrentie, of dat men zal trachten, door uitbreiding en door accaparatie van lijnen, die concurrentie te vernietigen. In het eerste geval zal men slechts geduldig kunnen afwachten, of de toekomst ook weder verbetering aanbrengt; in het tweede geval kan, naar het schijnt, de stontmoediger politiek met goeden uitslag bekroond worden, maar alsdan zal iedere teleurstelling ook dubbel gevoelig zijn. Thans staat in deze zaak naast een aandeelen-kapitaal van 29,000,000 doll. nog slechts een schuld van 10,700,000 doll.; de netto inkomsten over 1875 bedroegen $2,670,000$ doll., waarvan 661,000 doll. door de dienst der schuld geabsorbeerd werden; de vermindering in de bruto ontvangsten over de 12/m. van 1876 tegenover 1875 heeft bedragen 756,000 doll., waarvan over September 95000 doll., over Qetober 98,000 doll., over November 193,000 doll. en over December 176,000 doll. Men zal uit deze cijfers gewar worden, dat, da,ar tegenover vermindering van brnto ontvangsten, althans wanneer die van eenigszins blijvenden aard is, ook wel vermindering in de exploitatiekosten kamt, niets gevaar loopt dan het bedrag van het dividend der aandeelhouders; maar toch ook dat de vermindering der ontvangsten in den allerlaatsten tijd zoo aanzienlijk is geweest, dat, ging die aldus door, werkelijk spoedig alle winst voor de aandeelhouders opgehouden zou hebben; en indien de nieuw in de zaak te steken kapitalen dan geene voldoende uitkomsten opleveren, dan zouden, wijl deze kapitalen slechts te vinden zullen zijn door het opnemen van nieuwe leeningen, de aandeelhouders wararlijk in eenen onaangenamen toestand geraken. Wij zeggen volstrekt niet dat men daarvoor beducht behoeft te zijn; er bestaat mogelijkheid dat de moeilijkheden van het oogenblik overschat of overdreven worden, en al is dit niet zoo, dan heeft men toch de verklaring der directie, dat men vertrouwt door het aanwenden van geschikte maatregelen die moeilijkheden te boven te kunnen komen. Alleen een grondig onderzoek van den stand van zaken zal daaromtrent verder licht kunnen verspreiden.

Het is intusschen wel verklaarbaar, dat dit voorval hier grooten indruk heeft gemaakt. De Illinois-spoorwegfondsen hebben hier langen tijd eenen bijzonder goeden naam gehad, zoozeer dat ze door velen als een exceptioneel fonds werden beschouwd; menigeen, 
die nooit iets van Amerikaansche spoorwog-fondsen wilde weten, maakte eene uitzondering voor de gevierde "Illinois", dat meende men was ,iets anders." Het gevaar is groot, dat de teleurstelling, die de Illinois-zaak nu veroorzaakt, ook op de opinie voor alle Amerikaansche spoorweg-fondsen invloed zal uitoefenen; juister gezegd, dit schijnt reeds plaats te hebben. Het is een feit, dat de Amsterdamsche beurs, die in de eerste $9 \mathrm{~m}$. van 1876, vooral in het derde trimester, over het geheel kooper was van die fondsen, in de laatste maanden van het jaar, niet alleen die inkoopen gestaakt heeft, maar verkooper is geworden; de Illinoisgeschiedenis behoort onder de oorzaken dier wijziging in de stemming.

Is daar reden voof? Wij zouden dieper moeten doordringen in de studie van het verleden en van den tegenwoordigen toestand van den Mlinois-spoorweg en dan in vergelijkingen moeten treden met andere spoorwegen, om op de vraag, aldus gesteld, een antwoord te kunnen geven. Op die wijze in tal van bijzonderheden aftedalen, zoude echter groote moeilijkheden met zich mede brengen, en toch zouden wij blijven staan op een zoo beporkt standpunt, dat wij ons onderwerp niet geheel zouden kunnen overzien.

Het is namelijk niet onze bedoeling in beschouwingen en beoordeelingen te treden van speciale fondsen. Met de markt der Amerikaansche-spoorwegfondsen in het algemeen genomen, wenschen wij ons bezig te houden. Alle daar voorkomende fondsen te behandelen zoude ons te ver leiden, ook al stond ons daartoe de noodige detail-kenmis ten dienste, iets waarop wij geen aanspraak maken. Maar ook, wij herhalen het, wij zouden daarmede ons doel nog niet bereiken. De zaak is deze: het Illinois voorval heeft in herinnering gebracht, dat op het gebied der Amerikaansche-spoorweg-fondsen angels en voetklemmen liggen; de vraag is of men dat gebied mijden moet, of dat middelen gezocht moeten worden en te vinden zijn, om dat gebied te blijven betreden, maar die angels en voetklemmen te ontwijken.

Het is dezelfde vraag die door de voorvallen van 1873 werd gesteld, maar die destijds door eene zeer onjuiste voorstelling vani eenige feiten tot geene zuivere oplossing kwam, noch komen kon. De latere ondervinding heeft nu wel geleerd, dat de angst, die zich toenmaals van velen meester maakte, zonder oorzaak was; wij zagen reeds verleden jaar - in ons beurs-overzicht over Julij/Sept: hebben wij er op gewezen - verschillende fondsen terugkomen op den oorspronkelijken koers van uitgifte en dien overschrijden; 
daarmede is echter nog volstrekt geene afdoende oplossing aan de quaestie gegeven en deze blijft, wij worden er door de Mlinois geschiedenis an herinnerd, nog steeds aan de orde.

De zekerste weg om geen verliezen te lijden in de Amerikaanschespoorweg-fondsen zoude zonder twijfel zijn ze geheel te laten rusten; met het geven van zoodanigen raad maakt men zich het gemakkelijkst van de zaak af; ook zou het opvolgen van. zulk een raad den houders thans niet zoo zware verliezen berokkenen als na 1873 , vele verkoopen zouden nu zelfs nog aanzienlijke winst laten. Maar zouden onze kapitalisten daarmede werkelijk gediend zijn ?

Wij zijn groote voorstanders van kapitaalsbesteding in landbouw, handel, scheepvaart en nijverheid, daaraan in ieder opzicht de voorkeur gevende boven de belegging in vreemde fondsen. Wij zijn vast overtuigd dat, zal Nederland ooit weder terugkeeren tot den bloei van vroeger dagen, weder in Europa, voorzoover als onder veranderde omstandigheden mogelijk blijft, den rang innemen van dien tijd, een rang dien het ook dankte aan de betrekkelijk sterke kapitaals-formatie die toen hier plaats vond, het een onmisbaar vereischte is, dat de geldbelegging en handel in vreemde fondsen een meer bescheiden plaats inneme en het veld meer ruime voor toewijding aan landbouw, handel, scheepvaart en nijverheid. En niemand zeker ook die beweren zal, dat tegenwoordig alleen de overtollige kapitalen, de kapitalen die alzoo geen plaatsing zouden kunnen vinden, naar de fondsenmarkt stroomen; onbetwijfelbaar mag het integendeel geacht worden, dat op gezegde wijze voor een belangrijk deel der thans in buitenlandsche fondsen belegde kapitalen eene plaatsing te vinden zou zijn; plaatsing waarvan niet alleen de indirecte, maar ook de directe voordeelen de in de buitenlandsche fondsen gemaakt wordende renten in den schaduw zouden stellen, bepaaldelijk wanneer wij tot het veld, waarop die gewenschte toewijding van kapitaals- en werkkrachten zoude moeten plaats vinden, ook onze koloniën rekenen, gelijk natuurlijk het geval moet zijn.

Maar men moge hierover redeneeren zooveel men wil, men dient rekenschap te houden met de feitelijke toestanden. En nu is er in den laatsten tijd zeker wel eenige beweging in de ook door ons gewenschte richting; maar wanneer men let op de verdeeling van ons nationaal vermogen, ook de geschiedenis te dien opzichte raadplegende, dan kan men de overtuiging niet van zich afzetten, dat er hier vooralsnog is en nog wel geruimen tijd blijven zal - groote en onvermijdelijke behoefte aan buitenlandsche fondsen. 
Men raadplege de geschiedenis. In het bekende werk van I. de Pinto dd. 1771/72 "Traité des fonds de Commerce ou Jeu d'Actions" dat ten deele reeds in 1761 geschreven was, vindt men eene beschrijving en verklaring van den fondsenhandel in Holland, waaruit blijkt, dat de Amsterdamsche beursmannen van dien tijd niets meer zouden hebben kunnen leeren van de knapste en slimste fondsenhandelaren der Europeesche beurzen in onze dagen. En het blijkt verder uit des schrijvers mededeelingen, dat die handel, die bepaaldelijk ook in buitenlandsche fondsen werd gedreven o. a. in de Engelsche annuiteiten en in de aandeelen der Eng. Ind. compagnie, ontstaan was tengevolge der steeds toenemende geldbeleggingen in die fondsen, alsmede dat die zich niet bepaalde tot weinige personen, maar dat daarin algemeen deel genomen werd. $\left({ }^{*}\right)$

In het door J. Migt of door de Serionne gesehreven en in 1778 te Londen verschenen werk "La Richesse de la Hollande" en in de aanmerkelijk uitgebreide en verbeterde bewerking daarvan door Mr. E. Luzac, het meer bekende "Hollands Rijkdom" in 1780/83 te Leijden uitgegeven, wordt het niet minder duidelijk vermeld, dat in het tijdvak door die schrijvers behandeld de plaatsing der Hollandsche kapitalen in allerlei fondsen, speciaal in allerlei buitenlandsche fondsen, voortdurend in omvang en beteekenis heeft toegenomen, eerst naast aanwending in den handel, maar allengs zelfs dit meer en meer vervangende en verdringende. En al werden ook nu en dan aanzienlijke verliezen geleden in de opgenomen fondsen; erger nog, al werden ook op die wijze door de Hollanders zelven aan de Eugelschen en Franschen de middelen verschaft om hen in den wereldhandel te verdringen, niets kon dien stroom keeren.

De gegeven voorstelling van den stand van zaken wordt ook geheel bevestigd in de verhandeling van den heer A. Rogge en in die van Mr. H. H. van den Heuvel, beide destijds geschreven in antwoord op eene prijsvraag door de Hollandsche Maatschappij van Wetenschappen te Haarlem in 1771 uitgeschreven.

$\left({ }^{*}\right)$ Sprekende van de Engelsche schuld en van de omzettingen waartoe die aanleidiog geeft, zegt de Pinto, dat hij in Frankrijk en elders een aantal personen ontmoet heeft, die van dergelijken handel noch van die fondsen kennis bebben. "On m'a souvent consulté là dessus, vervolgt hij, et j'ai va avec étonnement, que les gens qui ont le plus d'esprit, ont le plus de peine à concevoir le détail de ce counmerce, que les esprits les plus dénués de sagacité entendent parfaitement en Hollande." Als verklaring daarvan zegt hij "il y a des choses qu'on ne conçoit jamais bien dans la théorie. La pratique seule enseigne le fond des choses. Il faut être nourri dans le sérail pour en connaitre les détours." 
Vijftig jaren later waren dezelfde vragen, die de genoemde schrijvers hadden bezig gehouden, weder aan de orde. De verwachtingen, die men gekoesterd had van verlevendiging van den handel na het herstel van den vrede in Europa, waren niet verwezenlijkt. Do zoo even genoemde Maatschappij vond daarin ook weder aanleiding, in 1825 , eene prijswraag uit te schrijven, die als een vervolg of eene hervatting van die van 1771 beschouwd kon worden. Eene ${ }_{n}$ verhandeling over de oorzaken van het.verval des Nederlandschen handels en de middelen tot herstel of uitbreiding van dezelve" door den heer J. van Ouwerkerk de Vries was het antwoord op die prijssvaag, aan hetwelk de gouden eereprijs toegekend werd. En wederom vinden wịj ook daar van de geschiedenis van die dagen opgeteekend, dat de handel en het spel in de fondsen en ook bepaald de geldbeleggingen in vreemde fondsen het noodige kapitaal aan den handel onttrokken,

Ook de regeering was in die dagen bedacht op het vinden van middelen om de kapitalen aan de deelneming in vreemde fondsen en negotiatien te onttrekken en te winnen voor nuttige inlandsche bedrijven; Gogel stelde in 1820 voor in zijn Eerste schets van eene voordragt van een geheel nieuw systhema van Finantien" dat, om tot dat doel te geraken, het successieregt voor alle vreemde fondsen verdubbeld zoude worden. „Veel, schreef hij, is er tegen het afleiden der kapitalen aan te voeren, en geringe middelen kunnen dienstbaar zijn om eene andere leiding aan den stroom te geven, terwijl somtijds geweldige te kort schieten." Werkelijk waren reeds geweldige middelen beproefd. De wet van 21 Aug. 1816 (Stautsblad No 33) hield in het „Verbod om eenige ligting van geld te openen voor eene vreemde mogendheid enz. zonder daartoe vooraf het consent van den Koning te hebben bekomen." De aanhef luidde aldus "Alzoo wij in overweging genomen hebben het nadeel, hetwelk aan den koophandel, het fabriekwezen en den landbouw, mitsgaders aan de publieke Nederlandsche fondsen wordt toegebracht, door openbare gelegenheid te geven, om de kapitalen welke anderzins tot uitbreiding en aanmoediging der voornoemde drie eerste bronnen van algemeene welvaart, of tot aankoop van nationale fondsen zouden worden besteed, in vreemde fondsen te plaatsen, zoo is het enz." Door de wet werden dan aan het openstellen van alle vreemde negotiatiën in Nederland zoodanige formaliteiten en bezwaren verbonden, dat het in de praktijk genoegzaam onmogelijk werd gemaakt. En juist het lot van deze wet toont beter dan iets anders hoezeor geldbelegging in vreemde fondsen 
in die dagen aan de orde was. In 1824 werd de wet ingetrokken, maar waarom? Dit vernemen wij in de Bijdragen tot de Huishouding van Staat van van Hogendorp. "Men dacht, schrijft hij, door middel van deze wet, de kapitalen in het land te houden, ter betere voortzetting van landbouw, nijverheid en koophandel. Het is gebleken uit de ondervinding dat men daarin niet is geslaagd. Men bleef vrij om zijn geld in Weenen, in Londen enz. te beleggen, en dit is ook zoo ruim geschied onder die wet, dat men juist daaruit besloten heeft, dat zij onnut was." In zijne verdere aanteekeningen betreffende deze aangelegenheid zegt van Hogendorp. ${ }_{n}$ Het beleggen van onze kapitalen in vreemde effecten is sedert lang eene zaak, waar veel vóór en tegen geschreven is. Ik heb er in den loop van vijftig jaar veel over gehoord." En hij meldt, dat, volgens een gezegde van den raadpensionaris van de Spiegel, de vreemde renten destijds, volgens waarschijnlijke berekeningen, veertig millioenen bedroegen.

Wij zien alzoo, dat het reeds eene zeer oude geschiedenis is die van de geldbeleggingen in Nederland in buitenlandsche fondsen, en dat sedert meer dan honderd jaar men bezig is middelen te verzinnen om aan dien stroom van kapitaalsbesteding eene andere wending te geven, zonder daarin geslaagd te zijn. Aan groote verliezen, daardoor voortdurend veroorzaakt, heeft het ook nooit ontbroken, vroeger evenmin als in lateren tijd $\left({ }^{*}\right)$.

Men behoeft zich dus geen illusies te maken, dat het licht zal vallen geldbelegging in buitenlandsche fondsen hier impopulair te maken, dat redeneeringen of harder lessen daartoe zullen voeren. En .al mocht het gelukken voor handel, scheepvaart, nijverheid en landbouw weder eens ruimer toevloed van kapitalen te winnen, het bedrag thans in buitenlandsche fondsen gestoken is toch zoo groot, dat daaraan honderde millioenen onttrokken kunnen worde

(*) Betreffende de verliezen in vroegeren tijd een enkel voorbeeld, warnit tevens blijkt op hoe grooten schaal men toen roeds de zaken dreef. In December 1772 veroorzaakte de daling der aandeelen in de Engelsch Indische Comp. - in Junij 224 pCt., waren ze in December op $155 \mathrm{pCt}$. teruggegaan, - een ware crisis aan de Amsterdamsche beurs. Men verhaalde - vernemen wij uit een toenmalig tijdschrift "Annales Belgiques* - van een particulier in Holland die roor zes millioen dezer andee.en in de liefhebberij was, en genoegzaam het geheele kapitaal der maatschappij wordt gezegd toen in Holland gehonden te zijn. Onder de fondsex, die in die tijden groote verliezen aan het Hollandsche kapitaal berokkend hebben, worden verder genoemd: oblig. Denemarken, Saxen, Silesië, Frankrijk, Oostfiriesland enz. 
zonder dat het zal ophouden een hoogst belangrijk aandeel van het totaal particulier vermogen in Nederland te vertegenwoordigen.

Eene berekening opgemaakt op het voetspoor van die van den heer A. P., als voorkomende in het Staatknndig en Staathuishoudkundig Jaarboekje voor 1875 , heeft ons tot de conclusie gebracht, dat met gerustheid, althans zonder vrees van overschatting, het totaal particulier vermogen in Nederland in 1872 kon geschat worden op ruim zeven milliarden, en dat daarvan ruim drie milliarden door publieke fondsen vertegenwoordigd werden, waarvan ongeveer twee derden door buitenlandsche fondsen en een derde door binnenlandsche; van deze laatsten bestond ruim de helft in Nederlandsche staatsschuld en de kleinere helft in provincialeen gemeentefondsen en aandeelen en obligatien van particuliere maatschappijen enz.

Men moet er dan wel toe komen, de buitenlandsche fondsen met het oog op onze beurs te beschouwen zoo als men dit belastingen moet doen. Niets is gemakkelijker dan er bezwaren van aan te wijzen en ze af te keuren, maar men kan er nu eenmaal niet buiten; heeft men dan geen beter equivalent aangegeven, zoo heeft men eigenlijk niets bewezen. Onwillekeurig zou men er zelfs licht toe komen, door een op zich zelven genomen goeden raad, slechte diensten te bewijzen. Toen b. v. velen hier in 1873 en 1874 Amerikaansche fondsen verkochten, kocht menigeen in de plaats daarvan obligatiën Spanje, Egypte, Peru, Turkije enz. Voor verscheidene Amerikaansche fondsen was de verkoop reeds op zich zelf slecht, maar hij werd het in ieder geval door de ruiling; al had men ook voor een deel de slechtste Amerikaansche fondsen gehad en alles gehouden, nog ware het beter geweest.

Men zij dus niet te haastig met de veroordeeling van de Amerikaansche spoorwegfondsen. Men vergete niet, dat de hoofdfondsen van de Amsterdamsche beurs altoos waren en nog zijn de buitenlandsche staatsfondsen; dat de Nederlandsche kapitalist voor dezen telkens en telkens weder eene groote voorliefde getoond heeft en toont, en zich ook waarijk niet bepaalt tot dezulken die door soliditeit uitmunten; dat veeleer hetgeen in fondsen als de Amerikaansche spoorwegfondsen hem bijzonder aantrekt, $t$. w. een betrekkelijk hooge rentabiliteit, ook in de buitenlandsche staatsfondsen door hem gezocht wordt, en die daar slechts te vinden is ten koste der soliditeit. Men bedenke welke verliezen die staatsfondsen aan de Nederlandsche kapitalisten hebben berokkend; wij laten de vorige eeuw nu daar en ook de tijjen van het eerste 
Fransche Keizerrijk, en herinneren slechts aan de ervaring opgedaan b. v. in $1830,1840,1848$ en 1859 , om voor den geest te brengen hoe door deze fondsen gedurig onherstelbare verliezen zijn veroorzaakt, en om aantetoonen dat de voorvallen der allerlaatste jaren waarlijk niet exceptioneel zijn.

Zoolang ook de ongezonde financiëele politiek, die schier overal nog in het staatsbeheer gehuldigd wordt, geen plaats gemaakt zal hebben voor geheel andere beginselen, en nog bovendien de tegenwoordige staatkundige toestand in Europa zal aanhouden, kunnen Staatsfondsen niet anders dan een gevaarlijk bezit opleveren. Welke waarde vertegenwoordigen, op weinige uitzonderingen na, de staatsschulden? Het zijn schulden gemaakt voor buitengewone wapeningen en oorlogen of tot demping van binnenlandsche onlusten, en dat zijn nog degenen die zich het best laten verantwoorden. Daarnaast staan anderen: gemaakt tot dekking van het deficit der staatsinkomsten tegenover de gewone uitgaven; veroorzaakt door den ondragelijken last, voortspruitende uit den voet van gewapenden vrede en uit de blijvende wapeningen à outrance, waaronder Europa sedert zoo vele jaren nu reeds gebukt gaat; ontstaan door dat de rente van vroegere leeningen niet opgebracht kon worden, enz. Dudley Baxter heeft berekend dat van 4100 millioen pd. st., dat in 1870 het totaal bedrag was van de staatsschulden over de geheele wereld, slechts 500 millioen tot dekking van productieve uitgaven hadden gediend. En al die schulden zijn er en blijven; lang reeds heeft hetgeen door de opgenomen gelden verkregen of tot stand gebracht werd uitgediend, maar de schuld is nog onafgedaan en blijft op het volk rusten. Wij denken hier niet alleen, niet in de eerste plaats zelfs aan landen als b. v. Turkijë, maar aan Frankrijk, Italië, Rusland, Oostenrijk. De Krim-oorlog vermeerderde de schuld van deze landen met millioenen en millioenen waarvan nog niets is afgedaan, en waar zijn op het oogenblik - behalve voor Italië - de vruchten van die uitgaven? Met milliarden heeft Napoleon III de schuld van Frankrijk vermeerderd, en wat is er door verkregen? Oostenrijk vermeerderde van 1848 tot 1868 zijn schuld van 1250 tot 3000 millioen florijn ten gevolge van zijne oorlogen tegen Hongarijë, Italië, Frankrijk on Pruissen; waar zijn de resultaten? Engeland zelfs, dat naast Nederland zich toch exceptioneel gunstig onderscheidt van alle overige Staten (de Ver. Staten van Amerika alleen uitgezonderd), Engeland heeft van 630 millioen pd. st., die de oorlogen van 1794 tot 1815 aan zijne schuld toevoegden, in de daarop gevolgde 
negenendertig jaar slechts ongeveer 100 millioen afbetaald; twee jaar van oorlog tegen Rusland voegden weder 34 millioen an de schuld toe, en veertien jaar waren noodig om deze som weder in te winnen en de schuld terug te brengen tot op de hoogte van vóór dien oorlog.

Waarlijk, in het algemeen genomen kan het niet bwijfelachtig zijn, waaraan de voorkeur voor geldbelegging gegeven moet worden tusschen staatsfondsen en aandeelen of obligatien in particuliere ondernemingen. A priori zoude men er toe kunnen komen de eersten onbepaald te veroordeelen; ook al neemt men daarbij niet eens in aanmerking, dat men daar altoos te doen heeft met eenen debiteur, die boven de wet staat en tegenover wien men dus volkomen machteloos is, eene overweging die toch ook niet van gewicht ontbloot is.

Maar niet alleen opdat men niet van kwaad tot erger vervalle, veroordeele men niet te spoedig de Amerikaansche spoorwegfondsen.

Zeer zeker is er misbruik gemaakt van de ondernemingsvorm, de naamlooze vennootschap, en is men zelfs in het gebruik dier vorm verder gegaan dan in verschillende opzichten wenschelijk is. Maar onmiskenbaar is toch het groote nut, dat door de naamlooze vennootschap gesticht is; de groote vlucht, die in de laatste halve eeuw in het bijzonder het bank-wezen, de fabrieks-nijverheid en de spoorwegen genomen hebben, ware zonder deze ondernemingsvorm onmogelijk geweest. Ze is een der factoren, waaraan de voorbeeldelooze toename der productie en van het algemeene welzijn in onze eeuw te danken is. En niet alleen het algemeen belang is daardoor gebaat, het zijn tegelijkertijd de particuliere belangen die daarvan groot voordeel hebben genoten. Door de onderneming in, of geldschieting aan naamlooze vennootschappen zijn aan de kapitalisten, groot en klein, tal van gelegenheden gegeven om hun kapitaal productief te maken in eene mate en op eene wijze, die anders onbereikbaar voor hen waren geweest. Daardoor is ook in het bijzonder, zoowel voor kleine als groote kapitalisten, de mogelijkheid ontstaan on deel te hebben in de voordeelen, die het in den regel afwerpt voor de kapitalen van oude landen om overgeplaatst te worden naar jonge landen, van de plaats waar de productieve kracht van het kapital kleiner is daarheen waar die grooter is; iets wat zonder de gebruikmaking van deze ondernemingsvorm slechts voor zeer weinigen uitvoerbaar is.

En onbetwijfelbaar is de aanleg en exploitatie van spoorwegen bij uitnemendheid gesehikt tot doel te strekken der naamlooze 
vennootschap, en stuit men dan niet op de bezwaren verbonden aan eene minder eenvoudige, scherp afgebakende werkkring, bezwaren die te meer wegen naarmate, door verwijjdering van plaats tusschen den zetel en werkkring der vennootschap en hare aandeelof obligatiehouders, het toezicht voor dezen moeilijker is. Even onbetwijfelbaar ook behooren juist de spoorwegen, waarbij het kapitaal zulk eene groote rol speelt, tot die ondernemingen, die op vitstekende wijze aan den kapitalist uit oude landen de gelegenheid aanbieden, om deel te hebben in de voordeelen der meerdere productiekracht van het kapitaal in jonge landen.

Dit dan - deelneming, hetzij als aandeel- of als obligatiehouder, aan buitenlandsche handels- of nijverheids- of landbouw- on in het bijzonder spoorwegondernemingen - dit is de meest wenschelijke en meest geschikte geldbelegging voor die kapitalen, die niet in eigen bedrijf of in dergelijke binnenlandsche ondernemingen, en voor ons land kan men hier ook gerust de nationale staatsschuld bijvoegen, emplooi kunnen vinden. En het ligt in den aard der zaak, dat men daartoe de ruimste en voordeeligste gelegenheid zal vinden in die landen waar de productieve kracht van het kapitaal het grootst is, waar aan vreemd kapitaal behoefte is, b. v. in Amerika.

Wij zouden daar nog bij kunnen voegen, dat bij goed overleg aan dergelijke geldplaatsingen ook nog groote indirecte voordeelen verbonden kunnen zijn. Nieuwe relaties en uitwegen kunnen daardoor geopend worden voor onzen handel en onze nijverheid, een nieuw veld van werkzaamheid voor onzen arbeid, hoogeren en lageren arbeid: voor onze ingenieurs $b$. v. en voor onze landbouwers. In sommige opzichten mogen wij dienaangaande niet in zoo gunstigen toestand verkeeren als Engeland dankt aan zijn ijzeren kolenproductie, toch ook voor ons is deel aan die voordeelen te bekomen. Het zoude ons echter te ver van ons eigenlijk onderwerp afleiden, indien wij hier langer bij stilstonden.

Van waar nu echter dat de ondervinding alhier voor eenige jaren opgedaan een zoo sterk démenti geeft - juister gezegd, schijnt te geven - aan deze theoriën?

Eene aandachtige beschouwing van de geschiedenis der wording en ontwikkeling van de markt der Amerikaansche spoorwegfondsen alhier zal ons het antwoord geven op die vraag, en daardoor zullen wij tevens menige nuttige les voor de toekomst kunnen opvangen.

Vooraf echter noæ eene opmerking. Indien wij schrijven, dat de 
ondervinding, hier voor eenige jaren opgedaan, in strijd is met hetgeen men volgens de ontrouwde theoriën zoude hebben mogen verwachten van opname van Amerikaansche spoorwegfondsen; zoo is het or toch verre van daan, dat wij ons zouden kunnen vereenigen met de jammerklachten, die in 1873/75 vernomen zijn naar aanleiding dier geldbeleggingen, en die ten slotte, Oct.INov. 1875, hunne uiting vonden in twee adressen aan de Tweede Kamer, het verzoek inhoudende tot het instellen eener Enquête. Men sprak van "een zwaar en zeer gevoelig verlies" dat ons nationaal vermogen geleden had, van, in de weegschaal gebrachte volkswelvaart" enz. Welnu, onderzoeken wij eens welke de omvang is geweest van de opname der Amerikaansche spoorwegfondsen in Nederland en van de daaruit voortgesproten verliezen.

Als uitgangspunt is door ons genomen een staat, voorkomende in het financiëel overzicht van het Zondagsblad dd. 24 Oct. 1875 en bevattende eene opgave van de genoemde fondsen, die geacht moesten worden destijds in handen van Nederlandsche houders te zijn, en van welken getuigd werd dat hij met de meeste zorg was opgemaakt. Schrijver dezes heeft destijds die opgaven voor een goed deel kunnen contrôleeren en dientengevolge er enkele wijzigingen in gebracht, maar dan ook de overtuiging bekomen, dat de aldus gewijzigde staat geacht mag worden zoo nabij mogelijk aan de werkelijkheid te zijn. Daarin zijn nog door hem opgenomen de oblig. $8 \mathrm{pCt}$. Florida, daar deze alhoewel staatsfonds toch ook aan den daaraan verbonden waarborg van eenen spoorweg hunne waarde ontleenden; voorts de fondsen der Maxwell- en der Costella-Martschappij : deze maatschappijen hadden landelijke ondernemingen ten doel, maar het faveur dat ze vonden stond toch te veel in verband met de beweging in spoorwegfondsen, dan dat ze daarvan af te zonderen zijn.

$B i j$ de nomenclatuur der fondsen en van de bedragen, waarvoor die geacht worden in handen van Nederlanders te zijn, gaat eene opgave van den tijd en van den koers der uitgifte of van den aanvoer alhier, van den hoogsten beurskoers in 1872 en van dien op 1 Nov. 1875, alsmede eene berekening der waarde van de opgegeven bedragen, zoowel tot laatstgemelden als tot den oorspronkelijken koers. De datum van 1 Nov. 1875 is gekozen, daar die zich aansluit aan het tijdperk der adressen an de Tweede Kamer. (Zie de Bijlage hierachter.) 
Het blijkt uit dezen staat (blz. 282-286), dat het bezit van Amerikaansche spoorwegfondsen, omstreeks genoemden tijd, eene waarde vertegenwoordigde van 174 en een oorspronkelijken koopprijs van 265 millioen gulden, dus een verlies had veroorzaakt van 91 millioen gulden. De oorspronkelijke opname is echter grooter geweest dan het bezit in November 1875 nog was, min of meer belangrijke bedragen waren toen reeds weder uitgevoerd. Hoogst moeilijk is het te berekenen wat dienaangaande het resultaat is geweest. Zulks is b. v. geschied met aandeelen Illinois Central, Chicago Rock Island, Pittsburg-Fort-Wayne en Baltimore Ohio, die over het geheel eene niet onaanzienlijke winst hebben nagelaten. Ook in aandeelen Union Pacific moeten winsten gerealiseerd zijn, ofschoon niet in verhouding van hetgeen daarvan een tijd lang hier gehouden werd en van de groote rijzing die later gevolgd is, daar veel reeds bij de eerste prijsverhoogingen verkocht werd. Ook aandeelen Milwaukee St. Paul zijn in veel grooter bedrag opgenomen dan Nov. 1875 nog aanwezig was, maar die realisatie heeft dooreen genomen zeker tot lager prijs plaats gevonden dan tot den genoemden koers. Wat aandeelen Chicago North Western aangaat, zoo staan tegenover het verlies op het vermelde bezit aanzienlijke winsten genoten op groote partijen, die meer dan eens tusschen Amsterdam en NewYork zijn omgezet en waarbij herhaaldelijk alhier goede rekening werd gemaakt. Van obligatien zijn er verschillenden waarvan posten weder uitgevoerd zijn. Zoo b. v. zijn zeker van de oorspronkelijk hier geplaatste obligatien Kansas Pacific wel 500.000 doll. weder verkocht geworden en dat betrekkelijk spoedig en tot ongeveer de hoogste prijzen d. i. eene winst van 10 à $15 \mathrm{pCt}$. nalatende; houders alhier verwisselden toen dit fonds, dat voor Duitsche rekening gezocht werd, tegen andere obligatien $b$. v. Denver Pacific, die lager aangevoerd en even goed geacht werden. Zoo zijn van gezegde Denver Pacific ook wel 500.000 doll. weder uitgevoerd en dat wel naar Amerika zelf, maar dit slechts ten deele boven den emissiekoers; voor een groot deel hadden die aankoopen voor Amerika slechts in den lateren, tijd plaats gevonden. Obligatien Central Pacific, Union Pacific, Chicago South Western, Atchison Topeka, North Missouri en Milwaukee St. Paul behooren in eene categorie van obligatien, waarvan de prijzen in Nov. 1875 al ongeveer gelijk stonden met die der emissies, na tijdelijk aanzienlijk hooger te zijn geweest en daarna ook merkelijk lager, en tevens onder die fondsen waarvan min of meer groote posten weder verkocht zijn geworden; maar, voor een deel althans, hebben die verkoopen plaats gevonden 
juist in de jaren 1873i74, toen de koersen van die fondsen op zijn slechtst en lager dan in Nov. 1875 waren. De vroeger plaats gevonden realisatien van de obligatien, die in Nov. 1875 het groote verlies gaven tegen den inkoopsprijs, hebben het totaal vérlies op dezen gewis niet verminderd, slechts bij een enkel soort zal dit het geval geweest zijn b. v. bij Californië Extensions; die realisatiën hebben intusschen zeker ook niet tot de allerslechtste prijzen plaats gevonden, zoo zijn er hier tijdelijk mogelijk 1.000.000 doll. Atlantic Mississippi obligatiën meer geweest dan in Nov. 1875, maar reeds in de prijzen van 70 à 60 en later omstreeks $50 \mathrm{pCt}$. werden die voor Engelsche rekening van hier weggekocht.

Iedere juiste taxatie van de resultaten van al deze en dergelijke omzettingen moet volkomen onmogelijk geacht worden, maair wij houden ons overtuigd veeleer te overdrijven dan beneden de waarheid te blijven, indien wij aannemen dat het bedrag van Amerikaansche spoorweg-fondsen, dat hier op zijn hoogst geweest is boven het in anzen staat opgevoerde totaal, twintig millioen dollar bedraagt, waarvoor een emissiekoers van $70 \mathrm{pCt}$. in doorslag gesteld moet worden, en dat het totale verlies verhoogd moet worden met $30 \mathrm{pCt}$. over gezegd montant. Wij komen dan op een resultaat van 300 millioen gulden als maximum aanleg-kapitaal en van 106 millioen als maximum der verliezen; en men gelieve wel acht te geven, dat wij niets in mindering dier verliezen hebben gebracht voor de zeer hooge renten, een tijd lang genoten over genoegzaam geheel het aangewende kapitaal, en die in Nov. 1875 nog altoos over ongeveer de helft daarvan genoten werden.

Zeker zijn de eijfers aanzienlijk. Een verlies van honderd milloen gulden, zioh verdeelende over drie jaar, is belangrijk: maar dat er geen -reden is om te spreken van $n$ gevoelig verlies voor ons nationaal vermogen," van "in de weegsohaal gebrachte volkswelvaart" zal, wanneer men aldus de feiten laat spreken, wel weinig verdere toelichting behoeven. Het kapitaal in de bewuste fondsen aangelegd heeft op zijn hoogst bedragen ongeveer $4 \mathrm{pCt}$. van het totaal der particuliere bezittingen, hoogstens $10 \mathrm{pCt}$. van het totale kapitaal in fondsen belegd of $15 \mathrm{pCt}$. van dat in buitenlandsche fondsen gestoken. Het maximum verlies is hoogstens $1 \frac{1}{2} \mathrm{pCt}$. van het totaal der particuliere bezittingen, ruim $3 \mathrm{pCt}$. van het in de fondsen in het algemeen, hoogstens 5 pOt. van het in de buitenlandsche fondsen belegd kapitaal, is dus hoogstens gelijk aan één jaar rente van laatstgenoemd kapitaal, en zich over drie jaar verdeeld hebbende, bedraagt het over dat tijdsverloop weinig meer 
dan een derde van hetgeen, naar eene door ons opgemaakte berekening, de jaarlijksche algemeene overwinsten of besparingen minstens beloopen. Eindelijk dient hier ten opzichte van het algemeene resultaat der operatie er nog eens uitdrukkelijk op gewezen te worden, dat de rente van de bedoelde Amerikaansche fondsen, voor zoover die voortdurend ongestoord genoten is en einde 1875 steeds genoten werd, minstens $4 \mathrm{pCt}$. bedraagt over het totaal der in die fondsen geplaatste kapitalen.

$\mathrm{Na}$ hetgeen roeds door ons in het midden is gebracht omtrent de geldbelegging en den handel in fondsen in het algemeen, zullen wij ook wel niet nader aan te toonen hebben dat er allerminst sprake van zou kunnen zijn, dat de opname van Amerikaansche spoorweg-fondsen hier oorzaak zou zijn geweest van een onttrekken der kapitalen aan landbouw, handel on nijverheid, noch ook dat deze een oorzaak is geweest van exceptioneele verliezen in de fondsen. Wat dit aangaat zijn de verliezen herhaaldelijk veroorzaakt door de voorliefde voor buitenlandsehe staatsfondsen, zonder eenigen twijfel, aanzienlijk grooter. Op enkele voorbeelden daarvan, in den allerlaatsten tijd, wenschen wij hier nog even de andacht te vestigen. De financieële verslaggever in het Zondagsblad (die daarbij dezelfde opmerking maakte) begrootte het bezit van Spaansche schuld in Nederland in 1875 op een nominaal kapitaal van 1100 millioen gulden. Naar eene door ons op deugdelijke gegevens opgemaakte begrooting, moest het bezit in 1872 niet hooger gesteld worden dan op 600 millioen als minimum, 900 als maxinum. Nemen wij 800 millioen als middencijfer, dan vinden wij. dat van 1872 tot einde 1875 dit ééne staatsfonds aan het particulier vermogen in Nederland een verlies van 100 millioen gulden veroorzaakt heeft; dus circa evenveel als het maximum verlies op alle Amerikaansche spoorweg-fondsen te zamen. Dat verlies is sedert nog met minstens 25 millioen vermeerderd. Daarbij voege men nu het verlies geleden in Turksche, Egyptische en Peruaansche obligatiën. En alleen maar de teruggang der koersen in 1876 heeft in dat jaar aan Nederland een verlies bezorgd van zeker 100 millioen op de Russische, en minstens 60 millioen op de Oostenrijksehe fondisen.

Komen wij thans tot de geschiedenis van de markt voor de Amerikaansche Spoorwegfondsen.

Hare wording dagteekent van 1866 à 1867 . Nergens hadden gedurende den Amerikaanschen burgeroorlog de Ver. Staten-obligatien een zoo gunstig onthaal gevonden als in Nederland. De omstandig- 
heden hadden de plaatsing alhier zeer in de hand gewerkt. De Europeesche oorlogen van den laatsten tijd en in het algemeen de politieke gesteldheid van Europa hadden een ongunstigen invloed uitgeoefend op de stemming van de Europeesche staatsfondsen. Pogingen destijds gedaan om den stroom der Nederlandsche geldbeleggingen eene andere wending te geven en die te winnen voor binnenlandsche industriëele ondernemingen, spoorweg-aanleg enz. hadden na een kortstondig succes weder schipbreuk geleden; waarschijnlijk niet het minst door de wijze waarop zij zelven, die zich aan het hoofd der beweging hadden gesteld, hun programma uitvoerden en het weldra geheel in den steek lieten. Daarbij kwam dat de opinie voor de Amerikaansche staats-obligatien hier altoos bijzonder goed was geweest; in de geschiedenis der vroegere schuld zag men een waarborg voor de toekomst. Schier zonder aarzeling en weifeling was en bleef men hier ook van den aanvang af overtuigd, dat de Noordelijke Staten zegevierend uit den strijd zouden komen, en toen de gebeurtenissen meer en meer dat vertrouwen wettigden en den uitslag minder twijfelachtig maakten, was men toch met Ver. Staten-obligatien nog op eenen koers die groote voordeelen aanbood; waardoor telkens nieuwe reeksen koopers opdaagden. Aanhoudend werden niet alleen nieuwe kapitalen in die fondsen belegd, maar ook in ruiling tegen andere fondsen werden ze opgenomen.

Zoo was allengs de schuld der Ver. Staten van Amerika het fonds par excellence van de Amsterdamsche beurs geworden, en deze opname van het staatsfonds is de middellijke en onmiddellijke oorzaak geweest van de opname der spoorwegwaarden. Aller aandacht was nu' eenmaal' op 'Amerika gevestigd, en de vitslag van den burgeroorlog rechtvaardigde volkomen het vertrouwen dat men in de kracht en vitaliteit der Noordelijken had gesteld; meer dan dat, hetgeen men toen zag gebeuren overtrof nog de stoutste verwachtingen van hunne vurigste bewonderaars.

Sedert is zooveel in Amerika voorgevallen en zooveel is anders uitgekomen dan het zich toen liet aanzien, dat men moeite heeft zich weder de indrukken van die dagen voor den geest te brengen. Men herleze echter eens de geschriften van dien tijd, b. v. het in 1867 verschenen werk van C. von Hock „Die Finanzen und die Finanzgeschichte der Vereinigten Staaten von Amerika." Dit werk kan niet verdacht worden een tendenz-gesehrift te zijn, dat aan financiëele ondernemingen den weg moest banen, maar was de vrucht van jaren lange studie van Amerika's toestand en 
geschiedenis, een wetenschappelijke arbeid door den schrijver ondernomen uit liefde zoowel voor zijn onderwerp als voor zijn eigen landgenooten, voor wie hij het leerrijk en nuttig achtte te zien, hoe Amerika zegenrijk moeilijkheden te boven was gekomen die, naar zijne meening, veel overeenkomst hadden met degenen waarmede men ook in Oostenrijk te kampen had. In zijn voorrede, in 1866 geschreven, aldus rekenschap gevende van de redenen die hem zijn arbeid hebben doen ondernemen en tot de uitgave deden overgaan, zegt hij dan verder: "de toestand van Europa wordt van dag tot dag treuriger en dreigender, de stroom der landverhuizing naar de weder tot rust gekeerde en zich vrij en krachtig opheffende Vereenigde Staten zal zelfs de hoogte, die ze in het vorige tiental jaren bereikte, weldra overschrijden en steeds meer ook die standen omvatten, die in de nieuwe wereld meer zoeken dan een vrij veld voor de aanwending hunner physieke krachten." Hij meldt hoezeer hij getroffen is door het schouwspel, dat de Vereenigde Staten in en na den oorlog vertoonden; $n$ ze waren aangrijpend en vol nuttige lessen de gebeurtenissen van het heden door de aan grootheid steeds toenemends inspanningen, door de eindelijke zegepraal van de zaak van de vrijheid en van het recht en allermeest door dien ongelooflijk spoedigen en rustigen terugkeer van een oorlogs- tot een vredesbudget, van een grenzenloos deficit tot een ongewoon hoog overschot van ontvangsten boven uitgaven. Legers en vloten zoo anzienlijk als nog nooit te voren gezien waren verdwenen met een tooverslag, de generaals van gisteren waren heden vreedzame handelaren," enz. In het bijzonder herleze men in dit werk het hoofdstuk getiteld: „De tegenwoordige toestanden en de waarschijnlijke verdere ontwikkeling."

Het was vooral het feit, waarop in de aangehaalde woorden gewezen wordt, dat in Europa grooten indruk maakte ten gevolge van het kontrast, dat daarin gelegen was met de Europeesche toestanden. Hier na iederen oorlog steeds nieuwe wapeningen, en iedere oplossing eener quaestie slechts nieuwe quaestiön aan den dag brengende; dáár de terugkeer van eenen algemeenen oorlogstoestand tot algeheele en volkomen toewijding aan de werken des vredes, en door den oorlog ook voor altoos uit den weg geruimd de eenige quaestie, waardoor de ontwikkeling van het land was bedreigd geweest: de slavenquaestie. Het vertrouwen was dan ook algemeen, dat Amerika zich spoedig van de gevolgen van den burgeroorlog geheel herstellen zou, zijn bloei en welvaart een tijdperk van verhoogden luister te gemoet gingen.

ECON, 1877. 
Van zelf moest dientengevolge de opinie wel gunstig zijn voor. de enkele spoorwegwaarden, die destijds hier. aan de markt waren of gebracht werden. Enkelen gaven zelfs aanstonds aan de spoorwegwaarden de voorkeur boven het staatsfonds; de spoorwegen, voor zoover zij niet materiëel van den oorlog zouden geleden hebben, moesten dadelijk de gunstige gevolgen van den vrede, der herleving: van handel, nijverheid en landbouw ondervinden, terwijl de omvang der staatssehuld het herstel van de staatsfinanciën altoos eeniggzins zou belemmeren, daaruit en uit het papienengeld altoos op, een gegeven oogenblik gevaren voor den schuldhouder konden ontstaan. Z100. begon reeds in 1866 de markt voor Amerikaansehe spoorwegwaarden naast die der Ver. Staten-obligatien eenige ontwijkkeling: te ondervinden; eene ontwikkeling die in de volgende jaren onafgebroken doarging om in 1869/71 eene nieuwe vlucht te nemen.

In de jarrverslagen van de. Kamer van Koophandel lezen wij: in het verslag o,ver $1866:$ : Het, waren echter niet alleen de genoemde staatsfondsen (Oblig. Ver. Staten v. Amerika) die bij groote partijen zoo voor geldbelegging als voor speculatie, on in. ruilhandel met vele andere markten, schier dagelijks werden verhandeld, maar ook verschillende Amerikaansche spoorweg-obligatien, welke op onze beurs met een weinig bekende levendigheid werden opgenomen;" in het verslag over 1867: „ ook in Amerikansche spoorweg-obligatien en aandeelen was de handel zeer levendig"; in het verslag over 1868: „De handel in NoordAmerikaansche spoorweg-waarden heeft in 1868 te Amsterdam eene: buitengewone uitbreiding erlangd"... ${ }_{n}$ Het Nederlandsche. publiek verraadt zekere voorliefde voor deze waarden, want elk nieuw dergelijk fonds vindt gretig aftrek"; in het verslag over 1869; „Bepaaldelijk Nederland, en Duitsehland blijven bij voortduring ten krachtigste de aanvragen voor Russische en Amerikaansche spoorwegen ondersteunen. De kapitalisten in beide landen geven ene ondubbelzinnige voorkeur aan de bedoolde vreemde spoorwegen, terwijl men in ons land op de spoorwegen onzer naaste omgeving zeer weinig de aandacht vestigt."

Wij hebben met opzet gezocht deze mededeelingen aan eene autoriteit te ontleenen, daar wij ons op het hien vermelde te beroepen hebben in de behandeling oener belangrijke quasstie, waarvoor wij, hier nog eens eene parenthese wensehen te openen.

Men heeft namelijk in de jaren 1873/75 herhaaldelijk hooren. beweren, dat een zeker aantal bankiers door de emissiën van Amerikaansche spoorwegleeningen, hoofdzakelijk in 1870 en 1871. 
voor hèvallen, dè óorzaak zijn geweest van de aanzienlijke geldbelegging in de A'merikaansche spoorwegwaarden, die hier hèeft plaats gevonden, en verantwoordelijk zouden zijn voor de daaruit voortgevloeide verliezen. Het onderwerp is te belangrijk dan dat wij daar niet even stil bij zouden staan. Wij hebben ons hier natuurlijk niet met de zaak bezig te houden met het oog op de betrokken emittenten. Wie daarin belang zou stellen moeten wij verwijzen naar de brochures, en naar de rapporten der vergaderingen wáarin die quaestie behandeld is. Maar indien onze beschouwingen ons tot juiste gevoilgtrekkingen zullen leiden, dan is het' noodig dat onze beobordeling van' het voorgevallene door geene onjuiste voorstellingen geprejudicieerd worde.

Welnứ. Uit de aangehaalde verslagen constateeren wij, dat de beweging is ontstaan en reeds, zoowel wat duur als omvang betreft, groote beteekenis had verkregen vóór de jaren 1870/71, hèt eigenlijke tijdperk der nieuwe emissies; dat vóór die emissies do vraag voor de Amerikaansche spoorweg-fondsen zich zelfstandig gevormd had. Op gevaar af van in eenige herhaling te vallen, moeten wij nog eens resumeeren en toelichten hoe dit zich heeft tỏegedragen. Pogingen aangewend om, hetzij ter wille van het doel zelf', hetzij ter wille der politieke en financiëele toestanden in Europa, den' stroom der geldbeleggingen in de eerste plaats voor handel en nijverhe ïd te winnen waren nièt gelukt. Zijn al nit die, door ons reeds herdachte, beweging van 1863/64 oenige particuliere fondsen an de beurs gebleven on hebben die daar burgerrecht verlkregen; Hebblen ook enkèle verdere pogingen, in dien geest gedaan, eenity súcees gehad; in hoofdzaak was de toestand der Amsterdamsche beurs in dit opzicht niet veranderd. De plaatsing in die jaren van een belangrijk kapitaal Rissische spoorweg-leeningen is met' deze bewering niet in strijd, daar die alleen gelukte ten gevolge der aan die leeningen verbonden staatsgarantie. Toch was de sympathie voor de oude geldbeleggingen in plasts van vermeerderd merkelijk afgenomen; de onzekerheid van den staatkundigen toestand van Europa was in de laatste jaren vóór 1870 steeds toenemende; de aanhoudende uitbreiding van de meeste Europeesche staatsschulden begon veler aandacht te trekken; en eene gebeurtenis als dei zoo'genaamde conversie; maar eigenlijk rentereductie der Oostenrijksche schuld veroorzaakte groote ongerustheid en "gaf aanleiding tot vele verkoopen niet alleen in de Oostenrijksche fondsen maar ook in de obligatien van andere Staten, die, vreesde men, slechts al te zeer geneigd zouden zijn zulk een voorbeeld te volgen. 
Daardoor hadden de obligatien Ver. Staten van Amerika hier grooten aftrek gevonden en, zoolang deze op speculatieven koers hadden gestaan, waren ze hoe langer zoo meer telkens en telkens weder bij alle geldplaatsingen en fondsenverwisselingen opgenomen. Maar op den pari-koers gekomen had het fonds veel van zijne aantrekkelijkheid verloren en in stede dat men het verder kocht, in stede vooral dat men zich ook met 5 pcts. obligatien Ver. Staten à pari tevreden stelde, toen de aflossing der 6 pets. weldra een aanvang nam, ontstond hier veeleer bij menigeen zelfs neiging om nu eens zijn winst te realiseren. Het was als eene belegging tot 7 , 8 ja 10 pet. dat men de Ver. Staten obligatien hier gekocht had, nieuwe even voordeelige plaatsingen werden verlangd, en het groote succes, dat de campagne in de Ver. Staten obligatien had opgeleverd, maakte zeer moedig. Het werd eene zoo niet onverdeelde toch door velen gedeelde opinie, dat eene dergelijke campagne in Amerikaansche spoorwegwaarden even voordeelige resultaten zoude opleveren.

Niet onverdeelde meening zeggen wij, ook dit dient inderdaad gereleveerd te worden. Er bestond van den aanvang af oppositie tegen deze beweging. Er werd als afschrikkend voorbeeld gewezen op de moeilijkheden waarin de ook hier bekende Atlantic \& Grea'Western spoorweg geraakt was en op de beruchte Erie-voorvallen. Daartegen werd echter aangevoerd, dat de manipulaties in Engeland in zake de financiën van den Atlantic \& Great-Western spoorweg niets tegen de Amerikaansche spoorwegen in het algemeen bewezen, en toen eerlang bleek dat, trots de verkeerde administratie dezer spoorwegzaak, de eerste hypotheek-obligatien volkomen " safe" waren, werd deze geschiedenis voor velen veeleer eene aanmoediging dan eene afschrikking. Dat eenige spoorwegaandeelen aan de New-Yorksche beurs tot groote speculatie, ja tot het meest roekelooze spel stof gaven, werd natuurlijk toegegeven, even als dat de Eric aandeelen als zoodanig vermaard waren, maar men wees er op, dat de hypotheek-obligatien dezer maatschappij op een zeer hoog standpunt onwrikbare vastheid vertoonden. Jeze en dergelijke contra-argumenten der voorstanders bevredigden evenwel niet alle oppositie. Tegenover hen die aan de Amerikaansche spoorwegfondsen hun vertrouwen schonken hebben steeds anderen gestaan, die ze met wantrouwen gadesloegen en die dit ook luide uitspraken. De genoemde verslagen der fondsenmarkt getuigen ook daarvan; dat trouwens algemeen in de pers verdeeldheid van opinie over het onderwerp heerschte on het daar aan geon polemiek ontbroken heeft, zal men zich wel herinneren. 
Twee zaken staan dus vast. De beweging heeft haren oorsprong gevonden bij het groote publiek zelf; en tegenover de voorstanders die de meerderheid vormden heeft het nooit aan tegenstanders ontbroken, waardoor eene voortdurende wrijving van gedachten, zich ook in allerlei geschrijf openbarende, ontstond. Tegenover dergelijke feiten de verantwoordelijkheid der beweging te willen schuiven op de emittenten gaat waarlijk niet aan

Zeker zoude men zich de mogelijkheid van een zoodanig geval kunnen denken. Gesteld dat de gelegenheid ter deelneming in eene zaak, die geheel nieuw en onbesproken ware, werd gegeven door een Huis dat weet, dat zijn naam wordt aangemerkt als een waarborg voor de deugdelijkheid van alle zaken, die het onder zijne bescherming neemt; dan zou de moreele verantwoordelijkheid van die geldbelegging op dat Huis nederkomen, vooral indien niet tevens mededeelingen gedaan werden, als noodig geacht konden worden tot het vormen van een zelfstandig oordeel over de zaak. Maar dit was toch waarlijk de positie niet in het geval dat ons thans bezig houdt. Al ware de loop van zaken niet zoo geweest als wij die gevonden hebben, nog hadden wij hier met een geheel anderen toestand te doen. De stand van zaken in Amerika in het algemeen, die van de spoorwegen in het bijzonder, konden door een ieder gekend en beoordeeld worden. Ook kan men niet zeggen, dat de bedoelde émittenten geene mededeelingen deden omtrent de door hen aangebrachte fondsen en daarvoor slechts op het gezag van hun eigen naam vertrouwen vroegen. Schier geen prospectus in die dagen, of het werd van brochures vergezeld en door verdere mededeelingen gevolgd.

Niet dat daarin reden kon bestaan, of vrijheid gevonden kon worden voor de emittenten om ter markt te komen met een fonds waarin zij geen vertrouwen zouden gesteld hebben, dat zij niet achtten te zullen voldoen aan de verwachtingen van hen die het zouden opnemen; vóór alles en vóór allen zal bij hen de overtuiging moeten hebben bestaan van de deugdelijkheid der door hen in handen genomen zaak. Maar dit is geheel iets anders dan op hen die verantwoordelijkheid te laden, zoo als sommigen gedaan hebben. Volgens dezulken zoude men tot de meening moeten komen, dat destijds de kapitalisten in Nederland in het algemeen en de Amsterdamsche beurs in het bijzonder onder de voogdij gesteld waren van een zeker aantal emittenten, en deze vrije beschikking over alle kapitalen hadden gekregen en daarvan toen misbruik maakten. Neen waarlijk - wat er ook zij van de Amerikaansche spoorweg- 
fondsen zelven - zóó was de toestand niet; en, zooals ook in de Tweede Kamer is opgemerkt bij het debat over het Enquete-verzoek, de emittenten die men alzoo verhoogt om ze op hetzelfde oogenblik zooveel te meer te vernederen, hebben noch dien overmaat van eerbetoon noch die onwaardigheid verdient.

De koopers hebben, niet aan eenen leiband loopende en zonder te weten of te kunnen weten wat zij deden, maar zelfstandig handelende, althans daartoe in staat gesteld, partij gekozen voor de voorstanders dier fondsen, ja zijzelven en niet de emittenten zijn de eerste voorstanders geweest. Als bewijs daarvan strekke, behalve het reeds aangevoerde, nog de herinnering aan het feit, dat verschillende fondsen zijn aangebracht, vooral in de eerste ontwikkelingsphase der markt, zonder dat het emitteerende of importeerende huis genoemd werd. Waarlijk was het dus niet de vlag die de lading moest dekken, want menigmaal ontbrąk de vlag zelfs geheel; en voortdurend - wij wezen er reeds op - werden bewijzen geleverd, dat men geene plaatsing wenschte eenvoudig op het krediet van zijn naam, maar op dat der zaak.

Eene andere bewering staat met dit onderwerp in het nauwste verband, het is deze: dat de markt in de Amerikaansche spoorwegfondsen door de emittenten gevormd is, niet door de beurs; dat door een vertoon van kunstmatige affaires de beursprijzen zijn gemaaakt en het publiek eindelijk meegesleept is, dat dan ook, als eenmaal de emissie geëindigd was en de emittent zijne hand van de markt terugtrok, de prijzen geen stand hielden en het fonds hoe langer zoo meer inzakte. Dit betoog vindt eigenlijk zijnen eenigen grond in wat aan het licht gebracht is door de Engelsche enquête, betreffende hetgeen te Londen heeft plaats gevonden met eenige Zuid-Amerikaansche staatsfondsen. Om aan te toonen hoe volkomen onjuist en ongegrond zoodanige bewering is. wat aangaat hetgeen hier voorviel, is het voldoende te verwijzen naar de feiten. Men raadplege den staat, door ons opgemaakt, aangevende de datums en koersen van uitgifte der bedoelde fondsen en hunne hoogste koersen met de datums van dezen. Dan zal men bemerken, dat schier algemeen eene aanzienlijke rijzing zich vertoond heeft een en twee jaar na de emissie of aanvoer, en indien men verder de dagelijksche noteeringen raadpleegt, zal men zien dat die door ons aangehaalde koersen ook niet exceptioneele affaires gelden, maar dat de koersverheffing zich geleidelijk ont wikkeld heeft en dat maanden lang het fonds zich in die hoogste prijzen bewogen heeft. Indien enkele fondsen zich nimmer boven 
hun emissiekoers hebben künnen verheffen, en integendeel spoedig na hunne verschijning zich in dalende richting hebben bewogen, dan is de eenige reden daarvan, dat ze uitgebracht zijn juist op het hoogste standpunt der markt, en natuurlijk hebben ze aan den algemeenen teruggang niet kunnen ontsnappen.

Eindelijk nog heeft men beweerd, dat het wel onloochenbaar is dat de beweging niet van de emittenten maar van de beurs is uitgegaan, maar dat dit juist de verantwoordelijkheid des eersten eer verzwaart dan vermindert, daar zij op die beursstemming zouden gespeculeerd hebben. Dit betoog heeft geene beteekenis indien het niet deze is, dat de emittenten gebruik gemaakt zouden hebben van eene bestaande beursopinie om fondsen aan te voereh, waarvan zij wisten of moesten vermoeden dat ze teleurstellingen en verliezen zouden veroorzaken; want dat een bankier zijne émissies doet dàn en dààr, wanneer en waar hij weet eene goede markt tè vinden, zal wel tot de eerste en door niemand te wraken beginselen van het bankiersbedrijf behooren. Voor dergelijke beschuldigingen of insinuaties is echter nooit een bewijs geleverd, wel is in véle gevallen het tegendeel gebleken; wij kunnen echter ook wat dit aangaat niet in bijzonderheden afdalen en zaken en personen gaan bespreken. Van ons algemeen standpunt en alle beoordeèling of rechtvaardiging van personen buiten quaestie latende, hebben wij echter dit op te merken, dat zelfs het bewijs der wararschijnlijkheid niet geleverd is, dat integendeel de waàrschijnlịjkheid tegen zoodanige beschuldigingen pleit. Onze bedoeling is het natuirlijk niet al wat voorgevallen is of kan zijn evenzeer te billijken en $\grave{a}$ priori onder onze bescherming te nemen, te bewerén dat in de beoordeeling van zaken en personen ook geen pláats zou zijin voơ nuances, maar wat wij bedoelön is het volgende. De uifḱmomst heéft bewezen dat er in de Ámerikaanschè spoorweg-fondseńbewegitig alhier misslagen zijn! begaan; ; op te spodren welké die geweest zijh is juist het doel dezer beschouwingen; mat het ontstand dier béweging on hare ontwikkeling. zijn zoo natuurlijk geweest, latteh zich zoo wel verklaren, dat er geen reden is te gelooven ain de inwerking van kurstmatige bevordering, gèen mogelijkheid schier om die te veronderstellen. De geheelé beweging getuigt verder van eene zoo algemeene, althans zoo predómineerende opinie ten voordeele dier fondsen, dat niets natuurlijker is dahi dat daarin dé emittenteri met het algemeene publiek op en buitèn de beurs één wiaren; die gunstige opinie bepaalde zich ook niet tot onze plàats en ons land, maar de méeste buitenlandsche fondsenmarkten, vooral 
de Duitsche markten: Frankfort, Berlijn, Bremen, Stuttgart, Munchen enz. deelden daarin. Die opinie eindelijk heeft zich zoo geleidelijk ontwikkeld en heeft zoolang aangehouden, als onmogelijk ware geweest indien ze niet op goede gronden gerust had, indien althans ze niet haar steun had gevonden in een standpunt, dat wel later gebleken kan zijn min of meer onjuist te zijn geweest, maar waarvoor toen goede redenen bestaan moeten hebben, en op welk standpunt ook emittenten zich bevonden kunnen hebben. Het is ten andere zelfs ondenkbaar dat, indien het gevaar, dat aan die fondsen verbonden was, zoo zichtbaar was geweest, het vooruitzicht der teleurstellingen die volgden zoo voor de hand had gelegen, als bij bedoelde bewering verondersteld wordt, dat $\mathrm{d}_{4 \mathrm{n}}$ de beweging zoo lang had kunnen aanhouden.

Wij keeren thans tot ons afgebroken verhaal terug.

In 1870 nam de beweging nog aanmerkelijk toe. Alle omstandigheden, die deze in de hand hadden gewerkt, waren dan ook in verdubbelde mate anwezig. De vrees voor ernstige politieke verwikkelingen in Europa in de eerste helft van het jaar, de DuitschFransche oorlog in de tweede helft, vervreemden hoe langer zoo meer de sympathiën voor de Europeesche staatsfondsen, en trots den oorlog bleef de geldmarkt - eene korte tusschenpooze uitgezonderd - zeer gunstig. Ook het einde van den oorlog, in 1871, bracht in dien stand van zaken geene verandering. Een wijle liet het zich aanzien dat de Fransche leeningen, die voor de deur stonden, hier veel deelneming zouden vinden; werkelijk waren daarvoor aanzienlijke kapitalen beschikbaar gehouden. De gebeurtenissen in Parijs echter deden hier de meening geheel omslaan; wel verre dat men in die leeningen ging inschrijven, werd men alhier zelfs verkooper van wat men aan Fransche fondsen gedurende den oorlog op de toen zoo sterk gedaalde koersen gekocht had. De rijzing die, van Duitschland uitgaande, in het najaar van 1871 volgde in de Oostenrijksche fondsen enz. lokte hier weder slechts verkoopen in die waarden uit. De geldmarkt was steeds gunstig en werd dit meer en meer ten gevolge der bekende geldmanipulatiën, uit de betaling der oorlogsschatting van Frankrijk aan Duitschland voortgevloeid. En bij dat alles dwongen nog de aanhoudende aflossingen van obligatien 6 pCts. Amerika den houders dezen ter markt te brengen.

Maar niet alleen dit. Niet alleen dat alles medewerkte tot de vatbaarheid voor opname der Amerikaansche spoorwegfondsen, in geen mindere mate waren het de berichten uit Amerika zelve, 
die de beweging in de hand werkten: de opinie zelve voor die fondsen werd nog voortdurend beter en won evenveel terrein, als de geschiktheid onzer markt om ze op te nemen.

De loop van zaken in Amerika in de eerste jaren na den oorlog, had de aanvankelijke verwachtingen niet teleurgesteld. Het was volkomen in overeenstemming met de algemeene impressie, wat de $n$ special commissioner of the U.-S. D. A. Wells in zijn rapport over 1869 schreef, namelijk: dat de ondervinding van het vervlogen jaar op het gebied van het kapitaal en de nijverheid der natie andermaal de getuigenis en bevestiging gaf der vernieuwing van die wondervolle mate van vooruitgang en ontwikkeling die, met uitzondering van het tijdvak van den burgeroorlog, de bijzondere karaktertrek was van de geschiedenis der Ver. Staten in de laatste vijfentwintig jaar. Zoo schreef o. a. The Economist in de Commercial History and Review van 1869, na de mededeeling van een antal verslagen en beschouwingen over den stand van zaken in Amerika: "It is tolerably clear that a process of rapid and solid recovery has been set in motion in the U. S."

Enkele statistieke opgaven mogen bewijzen, dat dergelijke impressies ook niet zonder degelijken grondslag waren.

Opmerkelijk was in de eerste plaats de hoogte, waarop in weinige jaren de belastingen gedurende den oorlog gevoerd en ook na dezen gehandhaafd konden worden. In het tiental jaren van 1851/61 bedroegen de totale uitgaven van het Federale Gouvernement in doorslag slechts ongeveer 58.000 .000 doll., in welke uitgaven hoofdzakelijk voorzien werd door de heffing van inkomende rechten. Gedurende en in de eerste jaren na den oorlog was de opbrengst der belastingen als volgt:

Inkomende rechten Goud dollars.

$\begin{array}{rr}1861-62 & 49.056 .397 \\ 1862-63 & 69.059 .642 \\ 1863-64 & 102.316 .152 \\ 1864-65 & 84.928 .260 \\ 1865-66 & 179.046 .651 \\ 1866-67 & 176.417 .810 \\ 1867-68 & 164.464 .599 \\ 1868-69 & 180.048 .326 \\ 1869-70 & 194.538 .374 \\ 1870-71 & 206.270 .408 \\ 1871-72 & 216.370 .286\end{array}$

Binnenl. belastingen Currency dollars.

37.640.787

109.741.134

209.464.215

309.226.813

266.027.537

191.087.589

158.356 .400

184.899 .756

143.098.153

130.642 .177 
De handhaving der belastingen op zoo hooge oijfers veroorloofde dadelijk met kracht de amortisatie der schuld aan te vangen; van September 1865 tot ulto. Junij 1869 werd reeds een bedrag van 268 millioen doll. afgedaan.

Ten opzichte der draagkracht van de bevolking voor de belastingen moet hierbij nog opgemerkt worden, dat nevens de vermeerdering der federale belastingen ook eene aanzienlijke verhooging was gekomen in die der bijzondere Staten; van 94.186.746 doll. in 1860 klommen deze op 280.591.521 doll. in 1870 .

Zien wij nu welke, ondanks deze verhoogde lasten en alle verdere nadeelige gevolgen van den oorlog, de vooruitgang is geweest in bevolking en welvaart.

\begin{tabular}{|c|c|c|c|}
\hline & \multicolumn{3}{|c|}{ De bevolking bedroeg in } \\
\hline & 1850 & 1860 & 1870 \\
\hline blanken & 19.553 .068 & 26.922.537' & 33.586 .989 \\
\hline vrijje kleurlingen & 434.495 & 488.070 & 4.880 .009 \\
\hline slaven ...... & 3.204 .313 & 3.953 .760 & - \\
\hline Chinezen .. & - & 34.933 & 63.254 \\
\hline Indianen .. & - & 44.021 & 25.731 \\
\hline & $\overline{191.8}$ & 31.443 .321 & 38.555 .983 \\
\hline
\end{tabular}

De vermeerdering is in het laatste tiental jaren wel percentsgewijze niet ondanzienlijk minder dan in het voorgaande, maar toch numeriek nog ongeveer gelijk. De betrekkelijke vermindering wordt algemeen uitsluitend aan de gevolgen van den' oorlog toegesehreven; Wells taxeerde dat. in 1869 de vermeerdering weder tot minstens 16100.000 gestegen was. Ten einde de beteekenis te doen uitkomen van de vermeerdering der bevolking, zoo als wij die in de Ver. Staten waarpernen, herinneren wij dat:

De jaarlijjksehe vermeerdering van bevolking bedraagt: in pet.

Engeland . . 1.29 de verdubbeling der bevilking rindt

Nederland . . . 1:01 dan plaats in jaren

Frankrijk ...0.35

54

69

198

en in Amerika vinden wij, het tijjdperk 1860-70 inbegrepen, de bevolking: in:

$\begin{array}{rrrr}1820: & 9.637 .909 & 1850 & 23.351 .207 \\ 1830: & 12.856 .407 & 1860 . & 314445.080 \\ 1840: & 17.400 .572 & 1870 & 38.877 .000\end{array}$

dat is verviervoudiging in 50 jaar, of verdubbeling ieder 25 jaar, 
De landverhuizing naar de Ver. Staten heeft bedragen

$\begin{array}{crrr}\text { in } & \text { personen } & \text { in } & \text { personen } \\ 1860 & 153.640 & 1866 & 348.554 \\ 1861 & 91.920 & 1867 & 298.358 \\ 1862 & 91.987 & 1868 & 297.205 \\ 1863 & 176.222 & 1869 & 385.287 \\ 1864 & 193.418 & 1870 & 361.238 \\ 1865 & 248.020 & 187.1 & 347.789 \\ & & 187.2 & 449.040\end{array}$

Dra na den oorlog nam deze dus weder eene groote vlucht en verder tamelijk regelmatig toe, het eijfer van 1872 is grooter dan ooit te voren bereikt werd; in 1854 , het jaar waarin voor dezen de meeste landverhuizers aankwamen, bedroeg hun aantal slechts 427.833. Uit de cijfers der landverhuizing in 1871-72 blijkt, mogelijk meer nog dan uit iets anders, hoe gunstig toen in Europa de algemeene appreciatie was van den.stand van zaken in de Ver. Staten.

De omvang der in kultuur gebrachte landerijen bedroeg
in 1870
tegen.
in 1860
163.110:720 Acres

188.921.069, A.cres

de waarde dezer hoeven:

$$
\text { 9.262.803.861 doll. } \quad 6.645 .045 .007 \text { doll. }
$$

Maar. nog veel aanzienlijker was de vooruitgang op het gebied van de fabrieksnijverheid, wij vinden:

\begin{tabular}{|c|c|c|}
\hline Aantal fabrieken & $\begin{array}{l}1870 \\
252.148\end{array}$ & $\begin{array}{r}\text { tegen } 1860 . \\
140.433\end{array}$ \\
\hline Arbeiders in de fabrieken & 2.053 .996 & 1.3.11.246 \\
\hline Waarde der fabrieken. & 2.118.208.769 doll. & 1.009.855.715 doll. \\
\hline $\begin{array}{l}\text { Betaalde loonen } \ldots \ldots \\
\text { Waarde der verwerkte }\end{array}$ & 775.584 .343 & $3788.878: 966$ \\
\hline $\begin{array}{l}\text { grondstoffen } \\
\text { ᄁ producten. . }\end{array}$ & $\begin{array}{l}2.448 .427 .242 " n \\
4.232 .325 .442 "\end{array}$ & $\begin{array}{l}1.031 .605 .092 \\
1.585 .861 .676\end{array}$ \\
\hline
\end{tabular}

Enkele cijfers betreffende de mijn-industrie verdienen ook alle aandacht.

Van steenkolen bedroeg de productie

$$
\begin{array}{llll}
\text { in } 1850 & 3.736 .186 \text { ton } & \text { in } 1871 & 34.037 .486 \\
& 1860 & 9.388 .758 & \text { ton }
\end{array}
$$

De produetie van ruw-ijzer bedroeg
in 1860
919.770 ton
in 1870
1.865.000 ton
$\eta 1865$
931.552 n
n 1872
$2,830.070$ 
De petroleum-bronnen werden voor het eerst in 1859 door middel van artesische putten in Pennsylvanië in exploitatie gebracht; dat jaar bedroeg de productie

$$
\begin{aligned}
& \text { ongeveer } 82.000 \text { vaten } \\
& \text { in } 1860 \# \quad 700.000 \# \text { waarvan }
\end{aligned}
$$

in Pensylvanië 600.000 , en 100.000 in West-Virginia en Ohio; sedert klom d's productie in Pennsylvanië:

$$
\begin{aligned}
& \text { in } 1861 \text { op } 2.113 .600 \text { vaten } \\
& \text { 》 } 1865 \text { »2.497.700 n } \\
& \text { n } 1869 \text { n 4.215.100 n }
\end{aligned}
$$

en in dat jaar in Virginië en Ohio op 365.000 vaten;

de uitvoer nam gestadig toe

$\begin{array}{rrrrr}\text { van } & 1.500 .000 & \text { galon in } & 1861 \\ \text { op } & 29.805 .523 & n & \eta & 1865 \\ 107.857 .571 & \eta & \eta & 1870 \\ \text { en ruim } 180.000 .000 & \eta & & 1872 .\end{array}$

De totale waarde van alle Invoeren en Uitvoeren bedroeg in millioentallen dollars

$\begin{array}{rrrrrl} & \text { Inv. } & \text { Uitv. } & & \text { Ivv. } & \text { Uitv. } \\ \mathbf{1 8 5 4 - 5 5} & \mathbf{2 6 1} & \mathbf{2 7 5} & \mathbf{1 8 6 6 - 6 7} & \mathbf{3 9 1} & \mathbf{3 1 4} \\ \mathbf{5 5 - 5 6} & \mathbf{3 1 4} & 326 & 67-68 & \mathbf{3 7 1} & \mathbf{3 7 5} \\ \mathbf{5 6 - 5 7} & \mathbf{3 6 0} & \mathbf{3 6 2} & \mathbf{6 8 - 6 9} & \mathbf{4 3 7} & \mathbf{3 2 5} \\ \mathbf{5 7 - 5 8} & \mathbf{2 8 2} & 324 & \mathbf{6 9 - 7 0} & \mathbf{4 6 2} & 420 \\ \mathbf{5 8 - 5 9} & \mathbf{3 3 8} & \mathbf{3 5 6} & \mathbf{7 0 - 7 1} & \mathbf{5 4 1} & \mathbf{5 6 2} \\ \mathbf{5 9 - 6 0} & \mathbf{3 6 2} & \mathbf{4 0 0} & \mathbf{7 1 - 7 2} & \mathbf{6 4 0} & \mathbf{5 0 1}\end{array}$

zijnde eene totale buitenlandsche handelsbeweging van 1854/55$1859 / 60$, zes laatste jaren vóór den oorlog van

of gemiddeld per jaar.

3.967.173.214 doll. en van 1866/67-1871/72, zes eerste jaren na den oorlog, van

of gemiddeld per jaar. 5.345.209.189 doll.

Eén onderwerp vereischt eene meer opzettelijke behandeling, namelijk de productie van het Katoen en in verband daarmede de algemeene toestand van het Zuiden.

Wij vinden de volgende productie-cijfers

$$
\begin{array}{rrrr}
\multicolumn{1}{c}{\text { in: }} & \text { Balen. } & \multicolumn{1}{c}{\text { in: }} & \text { Balen. } \\
1859-60 & 4.669 .770 & 1864-65 & 300.000 \\
60-61 & 3.656 .086 & 65-66 & 2.154 .476
\end{array}
$$

(*) In dit cijfer is eene belangrijke hoeveelheid begrepen afkomstig vau de voorgaande jaren, die toen niet naar de verschepingsplaatsen verzonden had kunnen worden, 


$\begin{array}{lrcr}\text { in : } & \text { Balen. } & \text { in: } & \text { Balen : } \\ 61-62 & 4.800 .000 & 66-67 & 1.951 .988 \\ 62-63 & 1.500 .000 & 67-68 & 2.430 .893 \\ 63-64 & 500.000 & 68-69 & 2.260 .557\end{array}$

Wells schrijft in zijn reeds genoemd rapport dat, terwijl in de eerste twee jaar na den oorlog de oogst van het katoen zoowel als van alle andere producten in het Zuiden grootendeels mislukte, daar de vrije arbeiders hooge loonen vroegen en slecht werkten, met 1868 een geheel andere toestand was aangebroken. Door vrijen arbeid, geholpen door werktuigen, die vroeger niet gebruikt waren noch konden worden, verkreeg men in dat jaar zoo gunstige resultaten, dat de productie der benoodigde levensmiddelen niet alleen voldoende was om allerwege goedkoop voedsel te verschaffen, maar om bovendien ruime reserves voor de toekomst te maken, terwijl de waarde der producten die uitgevoerd konden worden, katoen, suiker, tabak, enz. 300 millioen dollar beliep. En voor 1869 waren de vooruitzichten niet minder gunstig. Overal in het Zuiden zag men dan ook de bewijzen van herlevende welvaart, spoorwegen werden hersteld en bijgebouwd, magazijnen opgericht, enz.; vooral werden op ruimen voet nieuwe werktuigen aangeschaft ter verdere verbetering en vermeerdering der productie. De groote vraag - schreef Wells - of na de afschaffing der slavernij het Zuiden de noodige werkkrachten zoude vinden, was door de laatstelijk opgedane ervaring op de meest voldoende wijze beantwoord.

Tot besluit dezer opsomming van eenige bijzonderheden, vestigen wij de aandacht op het totaal der particuliere bezittingen in de Ver. Staten, zoo als de resultaten van den "Census" van 1870 die hebben leeren kennen.

Als totaal bedrag van de werkelijke waarde vinden wij

\begin{tabular}{|c|c|c|}
\hline & in 1870 & 30.068 .518 \\
\hline tegen & $\# 1860$ & 16.159 .616 .068 \\
\hline en & $n 1850$ & 7.135 .000 .000 \\
\hline
\end{tabular}

De vermeerdering van $1860-187 \theta$, ofschoon percentsgewijze niet even aanzienlijk als van $1850-1860$, is toch hoogst belangrijk; maar er is meer. Ten einde eene juiste vergelijking te maken tusschen den normalen vooruitgang in de twee tijdvakken, moet men den afbreuk, door den oorlog aan het nationaal vermogen gedaan, in aanmerking nemen; ten andere moet van het totaal der particuliere bezittingen afgetrokken worden het bedrag van de Schuld der Ver. Staten, die tegenover het actief als een post in het passief gesteld moet worden, en die in 1860 niet noemens. 
waard was: Wij komen dain tot het volgende resultaat: (wij nemen ronde sommon).

Waarde der part. bezittingen in $1870 \ldots 30.000 .000 .000$ doll. af Schuld der Ver. Staten " "

$$
\text { blijft } \frac{2.500 .000 .000 \pi}{27.500 .000 .000 \text { doll. }}
$$

bij te tellen het verlies door den oorlog veroorzaakt, bedragende volgens de berekeningen van Wells . . . . . . . . . . 9.000.000.000

$$
\text { is } 36.500 .000 .000 \text { doll. }
$$

Waarde der part. bezittingen in $1860 \ldots 16.100 .000 .000$,

is : Bruto waarde vermeerdering $1860-1870 \overline{20.400: 000.000 ~ d o l l . ~}$ of op 16.100.000.000 doll. . . . . . . . 126,7.0 pCt. tegen, waardevermeerdering $1850-1860$ van 7.100 .000 .000 doll. op 16.100.000.000 doll., 9.000.000 000 doll. of op 7.100:000.000 doll. . . . . . . . . . . . . . . 126,76 pCt. zijnde dus in het tijdvak $1860-1870$, ondanks den tusschentijds gewoed hebbende oorlog, eene percentsgewijze bruto vermeerdering, die volkomen overeenstemt met die van $1850-60$.

Men verkeerde bovendien in het tijdvak waarvan wij spreken (1869-71) in de beste verwachtingen van het bestuur van den President Grant, wions optreding algemeen met vreugde begroet was,y; zoowel ten wille zijner hooggeprezen bekwaamheid en rechtschapenheid, als in het bijzonder met het oog op de van hem verwachte. staatkunde tegenover het Zuiden en op financiëel gebied:

Inderdarad indien, men aldus den blik vestigt: op den stand van zaken in Amerika;, zooals die zich in die dagen voordeed, dan kan het geene verwondering baren, dat toen zoo gunstige opinie bestond voor de geldbelegging in Amerikaansche spoorwegwaarden. Daarbij vergete men! ook niet dat, indien overal de spoorwegen in ruime mate moeten deelen in de voordeelen van eene levendige handelsbeweging en van de ontwikkeling op het gebied van landbouw en van mijn-exploitatie, dit in het bijzonder zoo is in Amerika, waar ze in vele gevallen de eenige communicatie-wegen zijn. Er was voorts wel reden om aan te nemen, dat er buitengewone behoefte bestond aan de uitbreiding der spoorwegen. Uit den aard der zaak had de aanbouw van spoorwegen gedurende den oorlog in zijnen normalen gang vertnaagd moeten zijn, en vooral in het Zuiden waren nog daarenboven verschillende bestaan hebbende spporwegen verwoest. Daarnaast stond verder de gewigtige gebeurtenis van het tot stand komen van den eersten Pacific-spoorweg. 
In dien spoorweg begroette men eenen nieuwen handelsweg ran wereldbeteekenis, bestemd om geen mindere verandering in het wereldverkeer te brengen dan weleer de ontdekking van den weg langs de Kaap de Goede Hoop. Was het dan vreemd dat men in het tot stand komen van dien spoorweg, die in het oosten zijn uitgangspunt had te Omaha aan de Missouri-rivier, en in de naderende voltooiing van den Kansasspoorweg, die uitgaande van Kansas-city zich door Colorado met den grooten Pacific-weg moest vereenigen, dat men daarin eene gezonde reden vond tot de daarstelling van verschillende wegen, bestemd om de vereeniging van die groote lijnen met al de havens en handels of nijverheids-centrums van het oosten. te bevorderen:

En in de tweede plaats had het tot stand komen van dezen spoorweg nog eene andere beteekenis. Het is deze, dat daardoor een geheel nieuw veld geopend werd aan den wakkeren ondernemingsgeest in Amerika. Het verre westen, waarvan men eerst in de laatste jaren - ten deele juist tengevolge der onderzoekingstochten ondernomen ter opsporing van de beste route voor dien spoorweg - al den rijkdom had: leeren kennen, en dat tot dien tijd als een gesloten boek was geweest, ongenaakbaar door het gebrek aan middelen van verkeer met het oosten, zou nu getrokken worden in den kring der handels- landbouw- en nijverheidsbeweging; zijn goud- en zilvermijnen, zijn kolenvelden, zijn gras en bouwlanden zouden nu niet langer onbenut blijven; dáár opendie zich eene nieuwe en veelbelovende toekomst voor den nimmer rustende en nimmer ontbrekende immigrant. Daar deed zich ook debehoefte aan nieuwe spoorwegen gevoelen, want de noodige vertakkingen van den grooten centralen weg zouden diens werk moeten voltooien, om an de exploitatie dier streken al de vruchten te doen dragen die deze kon aanbieden, en het aan die spoorweg-verbindingen toekomende deel dier vruchten zou zich niet laten wachter.

Het gunstig oordeel voor geldbelegging in Amerikaansche spoorwegen heeft verder steeds voedsel gevonden in de voorwaarden waarop de gelegenheid daartoe gegeven werd. Slechts van zeer enkele maatschappijen heeft zich hier de plaatsing van aandeelen voorgedaan; de overgroote massa der hier geplaatste fóndsen waren obligatien. Die obligatien waren verkrijgbaar op voorwaarden, dis: volkomen bevrediging gaven aan de eischen van vaste en hooge rentabiliteit, die men hier stelde; en men meende in den aard derzelven eenen-waarborg te- vinden tegren het wisselvallige, dät alteos aan iedere spoorweg-onderneming verbonden is. Hét eigen- 
aardige namelijk der bedoelde obligatien is dat ze hypotheek-obligatien zijn, en door de aldus verkregen wordende hypothecaire rechten achtte men zich beveiligd tegen de gevaren van schuldvermeerdering, daarin zag men tevens eenen gemakkelijken weg om eventueel tot executie van het onderpand over te kunnen gaan Wel wist men dat het aandeelenkapitaal niet integraal in kontanten gestort was of werd; maar dat dit voor een deel diende ter betaling van diensten als kosten van opname, onderzoek en voorbereiding; voor een deel slechts de belooning vertegenwoordigde, aan de oprichters en ondernemers van den weg toegekend wordende, voor die diensten waarvoor bij ons oprichters-aandeelen of rechten en tantièmes van winst worden gegeven; dat somwijlen daarmede de eerste werken van den weg, als het maken van den aarden baan, op zeer ruimen voet betaald werden; of nog, dat tegenover afgegeven aandeelen stonden subsidies van county's en gemeenten, ontvangen in obligatien, die volstrekt geen pari-waarde hadden; in één woord, wel wist men dat in meerdere of mindere mate het aandeelen-kapitaal niet voor het volle bedrag beschouwd kon worden als vertegenwoordigende een surplus van waarde van den weg boven het bedrag van het obligatien-kapitaal; toch meende men in dat kapitaal een voldoend surplus te hebben. Al stelde het dan ten deele niet voor genoten diensten van materieele waarde, daartegenover stond, dank zij den vorm der hypothecaire geldleening, dat, zouden de obligatiehouders niet volle renten en ter zijner tijd aflossing genieten, dan den aandeelhouders alle bezit ontnomen zoude worden, en mell niet gedwongen zoude zijn eenige schikking aantegaan, zooals obligatiehouders die slechts concurrente crediteuren zijn dikwijls genoodzaakt zijn te doen. Dat feitelijk die toestand van obligatiehouder voldoende zekerheid gaf, daarvoor vond men ook een waarborg in hetgeen men omtrent het rendement der Amerikaansche spaorwegen vernam.

Het was wijders dat optreden als hypothecaire-geldgever, die, naar men meende, betreffende het hem toekomende geen. zorgen behoefde te hebben, dat maakte dat men zich niet afschrikken liet door hetgeen men vernam omtrent roekeloosheid en andere misbruiken in de administratie van eenige spoorwegen. Juist hetgeen men dienaangaande zag gebeuren, leverde het bewijs dat, al werden ook de aandeelhouders of het publiek de slachtoffers van zoodanige misbruiken, de belangen der obligatiehouders daardoor niet aangetast werden. Opmerkelijk is het wanneer men de Amerikaansche bladen dier dagen nog eens doorleest, dat men veel 
polemiek vindt omtrent spoorwegzaken en administratie enz. een polemiek waarvan de weergalm ook hier werd vernomen en die hier aanleiding kan gegeven hebben tot de oppositie door eenigen gevoerd tegen de spoorwegobligatien - maar steeds vindt men de overtuiging vast staan, dat de belangen der obligatiehouders daarmede niet gemoeid zijn. Het is zelfs dit feit, dat de voorname geldgever in den spoorweg - de obligatiehouder - veilig is, welke ook de fouten en misbruiken zijn waaraan direkteuren zich schuldig maken, dat, ter wille van plaatselijke belangen, de aanleiding geeft tot oppositie in eenige bladen tegen eene financieele organisatie waarvan dat het gevolg was ; in meer zamenhang tusschen de belangen van den geldgever en het publiek belang wilde men een middel vinden ter bescherming van dit.

Waar echter de weg nog niet voltooid was maar slechts in aanbouw, werd intusschen de deugdelijkheid van het hypothecair onderpand natuurlijk zooveel minder; maar, in vele gevallen althans, stond daartegenover de hypotheek die men verkreeg op den grond, die aan de maatschappij geschonken was door de subsidie der regering in den vorm van den landgrant. Door deze landgrants achtte men vooral ook de waarborgen verhoogd van de obligatien van spoorwegen, die in betrekkelijk nieuwe streken zouden aangelegd worden. Als een voorbeeld van de appreciatie daarvan schrijven wij af het slot van een artikel in het Bijblad van het Effectenblad (No. $38 A^{0} .1869$ ), in welk artikel de Union Pacific railway Southern Branch behandeld werd; wij lezen daar: „Dat wij op grond van alle deze omstandigheden aan Kansas een schoone toekomst beloven, zal niemand bevreemden. Wij twijfelen niet dat deze Staat, gelegen in het middenpunt der Unie, zoodra de spoorwegen zich uitbreiden, spoedig bevolkt zal worden, en is dit het geval, dan kunnen de maatschappijen weldra hare landerijen tegen billijke prijzen verkoopen; en er is geen twijfel dat de obligatien, door deze gronden gewaarborgd, binnen een niet al te lang tijdsverloop zullen worden ingekocht of afgelost."

Het is ook in verband met de gunstige opinie voor de landgrantspoorwegen, dat men de uitgifte moet beschouwen der obligatien van de twee landontginnings-maatschappijen, die wij reeds bij de opsomming der spoorwegfondsen onder deze opnamen. De landerijen, waarvan hier sprake was, bevonden zich bovendien juist in die westelijke streken, die het brandpunt schenen te zullen worden der ontwikkeling, in het leven geroepen door het tot stand komen van den Pacific-spoorwég. 
Wij hebben opgemerkt dat men voor de zekerheid van den toestand als obligatiehouder ook een waarborg vond in hetgeen men betreffende het rendement der Amerikaansche spoorwegen vernam. Door eenige statistieken wenschen wij omtrent den toenmaligen stand van zaken een en ander in herinnering te brengen. Ons staan daartoe echter niet ten dienste die volledige overzichten en uitvoerige mededeelingen, die men vindt wanneer men den tegenwoordigen stand van zaken wil leeren kennen. Intusschen zal toch over verschillende punten genoegzaam licht geworpen worden.

In eene verzameling van financieele opgaven over Amerika in 1868 door Belding Keith \& Co. te Londen uitgegeven, vinden wij de volgende opgave van den k̦ostenden prijs der Amerikaansche spoorwegen in 1867 :

Noord Oostelijke (of Nieuw

$$
\begin{array}{ccc}
\text { Mijlen } & \text { Kostende prijs. } \\
\text { in exploitatie. } & \text { Totaal. } & \text { per Mijl. }
\end{array}
$$

Engeland) Staten . . . 3926 \& 166.435 .366 \& 42.367

Middel Oostelijke Staten . . $9559 \quad$ 526.113.091 $\quad \mathbf{5 5 . 0 5 3}$

Zuid Oostelijke $\quad$. . . . 5489 " 54 140.453.949 ${ }_{n} \mathbf{2 5 . 5 8 9}$

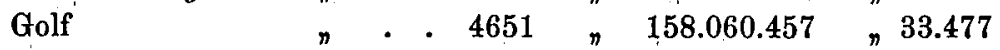

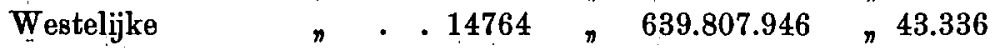

Pacific $n$. $.432 \quad 4 \quad 29.590 .000 \quad{ }_{n} 68.495$

$38821 \& 1.660 .460 .809 \$ 42.797$

Dit koṃt tamelijk wel overeen met hetgeen Poor in zijn Manual voor 1869/70 aangeeft; hij schrijft geen juiste cijfers te kunnen mededeelen, maar dat men kan aannemen:

voor de Nieuw Engeland Staten ongeveer . . . . 40.500 doll.

$\begin{array}{llllllllll}n & n \text { Middel } & n & n & . & . & . & . & 55.000 & n \\ n & n \text { Zuidelijke } & n & n & . & . & . & . & 30.000 & \\ n & n \text { Westelijke } & n & \text { even } & \text { als } & \text { voor } & \text { den } & & & \\ \text { algemeenen doorslag } & \text { ongeveer } & . & . & . & . & . & . & . & 44.000\end{array}$

en hij begroot den totalen kostenden prijs van 42.255. mijlen, dio in 1868 in exploitatie waren, op ongeveer $1.850,000.000$. In zijn Manual voor 1870/71 bevestigt Poor deze gegevens, en de totalc kostende prijs van toenmaals 47254 mijlen wordt door hem in ronde cijfers op 2.000.000.000 doll. begroot. Als kostende prijs wordt hier steeds bedoeld het nominale kapitaal in aandeelen en obligatien, dat volgens Poor minstens een derde meer bedroeg dan het werkelijk geréaliseerde kapitaal.

De ontvangsten worden door Poor begroot in 1869 te zijn geweest in doorslag 10,000 doll. per mijl; in Massachussetts hadden ze be- 
dragen in 186815.400 doll. per mijl, in den Staat New-York 13,142 doll., in Pennsylvanië 13,900 doll., in Illinois ruim 10.000 doll.; als totaal eijfer neemt Poor voor 1869400.000 .000 aan.

Volgens deze opgaven beliepen dus destijds de bruto-inkomsten der spoorwegen in de Ver. Staten dooreengenomen twintig pCt. van het nominale aandeelen- en obligatien-kapitaal. De exploitatiekosten aannemende op $70 \mathrm{pCt}$., wat ruim genomen is, laat dit een rendement over van $6 \mathrm{pCt}$. over het totale nominale kapitaal, of meer dan $12 \mathrm{pCt}$. over het obligatien-kapitaal dat wel de helft van het totaal bedraagt.

Intusschen hebben wij hier te doen met opgaven, die op geen volkomen juistheid aanspraak kunnen maken. Maar in eene door Robert Giffen met zorg opgemaakte statistiek betreffende 1871 vinden wij deze uitkomst in hoofdzaak bevestigd.

Wij ontleenen aan Giffen's mededeelingen den staat op volg. pag.

Giffen merkt omtrent de door hem opgemaakte resultaten op, dat, ofschoon enkele spoorwegen buiten aanmerking hebben moeten blijven bij gebrek aan opgaven dienaangaande, het aantal van deze toch zoo gering is, dat men uit de medegedeelde cijfers niet alleen den gemiddelden toestand leert kennen, maar genoegzaam den feitelijken toestand.

Het zign evenwel slechts totaal cijfers en zoo als Mr. N. J. den Tex in zijn bekend geschrift over de Amerikaansche spoorwegen, in 1873 uitgegeven, aangaande Giffen's arbeid zeide, voor de beoordeeling van eenigen specialen spoorweg heeft dit geen nut. $W i j$ zien echter daaruit, gelijk wij ook van Poor vernamen, dat in het algemeen genomen de Amerikaansche spoorwegen in de dagen, die wij op het oog hebben, in gunstigen toestand verkeerden; het verkeer, de vrachten, de exploitatiekosten, de verhouding tusschen netto-inkomsten en kapitaal waren van dien aard, dat zelfs op het totale nominale kapitaal een voldoend rendement werd verkregen, en de rente van het obligatien-kapitaal werd zeer ruim gedekt. Alleeni de Pacific-lijnen zagen de rente hunner leeningen in 1871 nog niet geheel gedekt, maar onder het bedrag dier leeningen waren de aanzienlijke subsidiën der Ver. Staten en het verkeer op die wegen was in gestadige toename.

In werkelijkheid was destijds de' toestand ook niet alleen in doorslag gunstig, maar was dit algemeen het geval. Was er al een enkele spoorwegmaatschappij die niet aan hare verplichtingen voldeed, het was eene uitzondering. In eene opgave van Belding Keith 
304

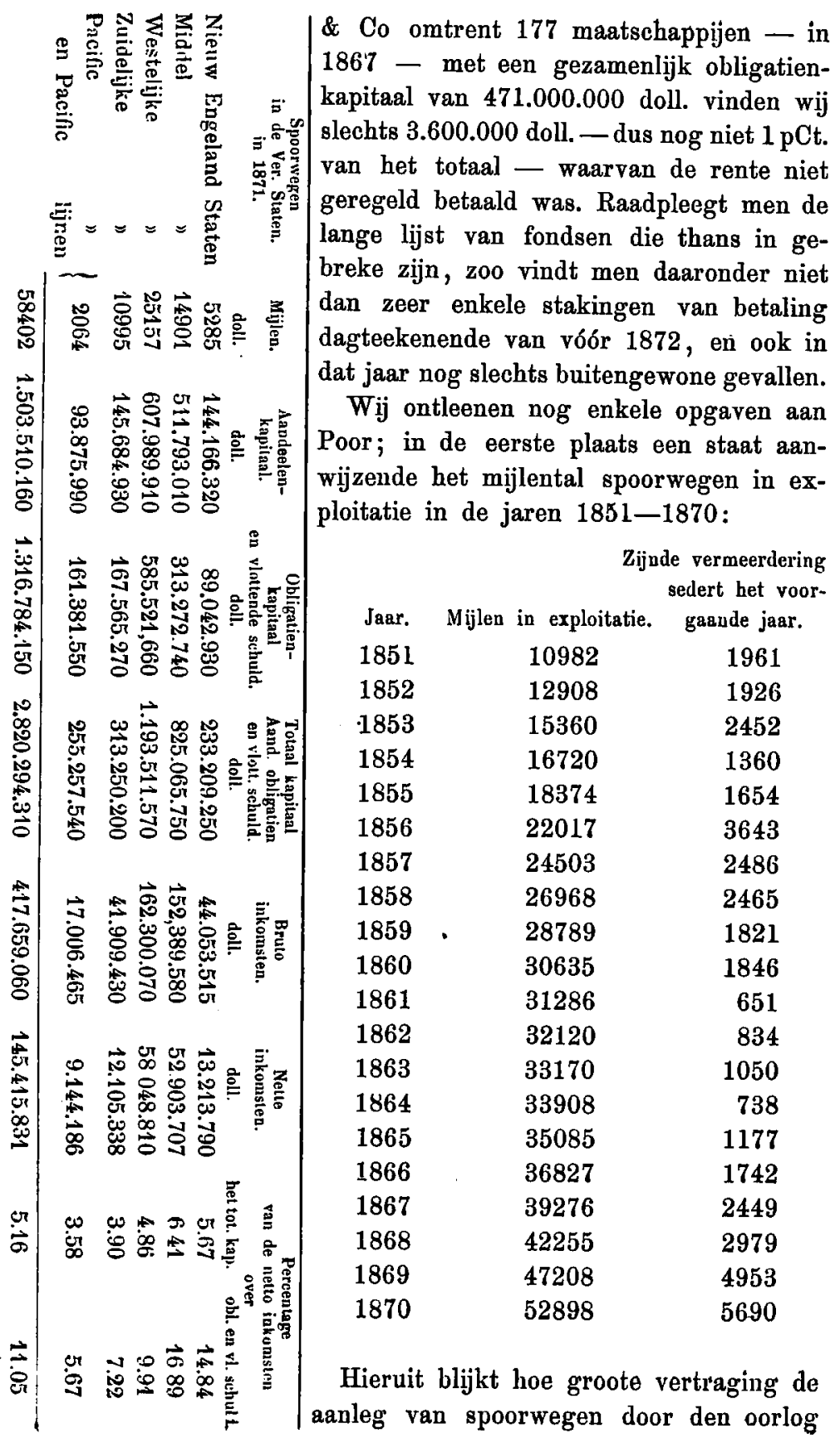


ondervonden had, en dit in aanmerking nemende en dat dus een buitengewone aanbouw in de eerstrolgende jaren het evenwicht slechts herstelde, ook nog in aanmerking nemende de bijzondere aanleiding die bovendien voor uitbreiding van het spoorwegnet bestond - waarop wij reeds gewezen hebben - zoo begrijpt men dat in de vermeerdering van het mijlental van $1867-1870$ geen reden van verontrusting gezien werd. De uitbreiding van het verkeer overtrof trouwens de uitbreiding van het spoorwegnet.

Volgens Poor vinden wij het volgende resultaat:

in

$185 \mathrm{l}$ totaal der ontvangsten op alle spoorwegen.

39.456.358 doll.
Jaarlijksche toename der ontvangsten.

\section{1 \\ 31256 \\ $130.000 .000 \quad n$ \\ $1851 / 619.000 .000$ doll. \\ $1861 / 7132.000 .000$

$187160852 \quad 454.969 .000$ ”

10982

of van 1851-1861, tegen bijkans 200 pCt. vermeerdering van het mijlental, 225 pCt. vermeerdering der inkomsten; van 1861-1871, tegen $100 \mathrm{pCt}$. vermeerdering van het mijlental, circa $250 \mathrm{pCt}$. vermeerdering der inkomsten, dus meer dan verdubbelde toename van dezen.

Hoe dan ook destijds in Amerika gedacht werd over de vermeerdering der spoorwegen, moge blijken uit het volgende. In 1870 schreef Poor. "We may calculate upon the steady progress of railroads in the Northern, Middle and Western States till a mileage of 90,000 miles in place of an existing mileage of 35000 miles, is reached." Hij rekende dat het mijlental in de NieuwEngeland staten driemaal, in de Middel-staten tweemaal, in de Westelijke staten driemaal de toenmalige uitbreiding moest bereiken om in de behoeften te voorzien. In 1872 woes hij andermaal op de gestadige toename der bevolking, van het verkeer en van de inkomsten der spoorwegen, en weder schreef hij: „With such results, the eagerness of our people to construct railways cannot be wondered at; the construction of these works must proceed at a rapid rate, till the aggregate shall exceed many fold the present mileage."

Nog eens dan, indien men, zoo als wij thans gedaan hebben, zich weder in gedachten plaatst tegenover de berichten die in de jaren 1866-1871 of 1872 uit Amerika werden ontvangen betreffende den vooruitgang der stoffelijke welvaart aldaar, en wederom de stemmen opvangt, die destijds van daar vernomen werden en die getuigden van groot vertrouwen in de gunstige beteekenis van 
hetgeen men waarnam en in den duur van den vooruitgang waarvan getuigenis afgelegd werd; zoo kan het geen verwondering wekken, dat men in Europa zeer geneigd was zijn kapitalen daarheen te zenden, om die te doen deelen in de groote daar te behalen voordeelen.

Maar slaan wij hetgeen destijds voorging gade onder het licht, dat daarop door de uitkomst geworpen is; nemen wij voorts in aanmerking een en ander dat sedert is voorgevallen; zoo zal het ons duidelijk worden waarom de toenmalige verwachtingen niet bevredigd zijn.

In de eerste plaats is de welvaart, die men meende te bespeuren, gebleken minder groot te zijn geweest dan ze scheen. Er was in een deel daarvan iets kunstmatigs en dat degelijken grondslag miste.

De regering verschafte zich in den oorlog de middelen om in de behoeften van dezen te voorzien - wij merkten dit reeds op o. a. door een uitgebreide belastingheffing, aanvankelijk alleen door inkomende rechten, weldra ook door binnenlandsche belasting: accijnsen, inkomsten-, patent- en zegelbelasting enz. en daarnaast door de uitgifte van papierengeld en van staats-obligatien. Onder den invloed nu van het buitenlandsch en binnenlandsch tarief, alsmede van de vermeerdering der circulatiemiddelen, veroorzaakt door de telkens toenemende uitgifte van papierengeld, ontstond eene aanzienlijke opdrijving van alle prijzen. De particuliere belangen werden daardoor gebaat, wijl de groote vraag, die bij de regering bestond, voor een aantal gemanufactureerde goederen zoowel als voor de producten van den landbouw, ter voldoening aan de behoeften van het leger, oorzaak was dat tot steeds klimmende prijzen de vraag voor alle producten het aanbod geheel dekte. Hoezeer dit ten voordeele strekte der particuliere belangen, blijke uit het volgende. Aanvankelijk was het de populariteit van den oorlog die de belastingen zonder morren deed dragen; het land was rijk, twee generaties lang had men zich geen opofferingen voor het algemeene welzijn behoeven te getroosten, en de algemeene verspreiding van den rijkdom maakte het een ieder gemakkelijk thans zijn aandeel in de belastingen optebrengen; met een zekere opgewondenheid en met fierheid over de grootsche resultaten van een stelsel van belastingen, dat in vier jaar de ontvangsten van de schatkist, uit dien hoofde verkregen, van $42,000,000$ op 310,000,000 doll. deed klimmen, kweet men zich van zijn plicht. Maar allengs was er geen sprake meer van opofferingen bij een ieder, die op eenigerlei wijze producent was; het bedrag aan belasting 
te betalen: op de grondstoffen, als patent, als inkomsten belasting enz. kon door den producent worden opgenomen in zijne kosten van voortbrenging en, zijn winst percentsgéwijzè berekenende over het totaal van dezen, werd aldus de belasting hem een nieuwe bron van verdienste in plaats van in mindering daarvan te komen. Buitengewone winsten kwamen daarbij wanneer de accijnsen of inkomende rechten eene nieuwe opvoering ondervonden; aan zoodanige verhooging werd dan geene terugwerkende kracht toegekend, en al het avans op de voorraden werd door de prodacenten of speculanten genoten. Herhaaldelijk was zelfs het oogmerk dergelijke winsten te behalen de eenige oorsprong van bewegingen op touw gezet om zoodanige tarief-verhoogingen te verkrijgen en, gesteund door al den invloed waarover de speculantén konden beschikken - en deze aarzelden niet zich daartoe, zoo uitvoerbaar, ook van omkooperij te bedienen - gelukten dergelijke bewegingen menigmaal. Zoo is het later gebleken, dat bij de verhooging van den accijns op brandewijn enz. op 1 Januarij 1864, er een tot het voorgaande tarief veracijinsde voorraad gereed gemaakt was, voldoende ter voorziening in de consumtie gedurende twaalf à achttien maanden.

Maar vaarden bij die financieele politiek der regering de particuliere belangen wel, de Staat, door zijn groote leverantien voor het leger de groote of finale afnemer van alle producten zijnde, droeg er de kosten van; terwijl hij zijn goud-obligatien steéds à pari tegen betaling in papierengeld uitgaf. Daar echter de belangen van den Staat wel geèn añdere zijn dan de algemeene belangen, zoo kan er hier eigenlijk geen sprake zijn van welvaart, die trots den oorlog in het leven werd geroepen, maar alleen van eene kunstmatige welvaart, veroorzaakt door verkeerde maatregelen in den oorlog genomen en van welke het eind den last moet dragen. Verschillende oorzaken zouden echter nog lang na het einde van den oorlog de reactie voorkomen, en de aangenomen financieele politiek zou ook tot verdere maatregelen leiden, door welke het zelfbedrog en de begoocheling nog langer aanhouden, mäar ook het kwaad nog evenveel verergerd worden zouden.

Alvorens daarop nader de aandacht te vestigen, moeten wij echter nog stilstaan bij enkele bijzondere belángen. In de eérste plaats verdient de uitvoer van tarwe en tarwemeel vermelding: Terwijl te voren bij een prijs van 41 of $40 \mathrm{sh}$. per quarter voor tarwe in Engeland, de uitvoer uit Amerika genoegzaam stilstond, in 1859 bij een prijs van 439 de uitvoer slechts $861.000^{\circ}$ bushel 
had bedragen, klom nu bij een prijs van $44 / 9$ on $40 / 2$ (gemiddelde prijs 42/5), in 1863 en 1864 , de uitvoer in deze beide jaren tot 67.000 .000 bushel, zegge 33.000 .000 per jaar. Dit was weder een gevolg van de papieren-geld circulatie en daarnit voortvloeijende premie op het goud. De invloed van dergelijken toestand laat zich onmiddelijk gevoelen op export-artikelen, het is dan het buitenland dat betaalt en men realiseert dus den buitenlandschen prijs plus het goud-agio, maar eerst langzamerhand volgt de prijsverandering der artikelen, welker omzet zich tot het binnenland beperkt; zoo kon de landbouwer herhaaldelijk tot gunstige realisatien overgaan, door dat de verhouding tusschen de prijzen, voor tarwe enz. te bedingen en die voor arbeidsloon en voor de grondstoffen der binnenlandsche productie te betalen, tijdelijk verbroken was ten voordeele der eersten; voorts vond hij nog groot voordeel in den verkoop tot een prijs, zij het laag in bet buitenland, toch dank zij de goud-premie hoog in het Amerikaansche papierengeld, dat tot wettig betaalmiddel verheven was, wanneer hij met dat provenu schulden of hypotheken kon afdoen, aangegaan in een tijd toen het goud nog geen agio deed. Op die wijze zijn aanzienlijke bedragen schulden en hypotheken afgedaan tot groot voordeel van den schuldenaar; de schuldeischers daartegen konden zich weder dekken door de goud-obligatien van den Staat eveneens à pari te nemen. Maar ook deze buitengewone bloei van den landbouw miste eenen degelijken en blijvenden grondslag.

Het minst bevoordeeld door den loop van zaken was de loonarbeider. De loonen - wij wezen er reeds op - volgen prijsveranderingen, als waarvan hier sprake is, slechts traag; eene vergelijking der prijzen gedurende den oorlog van alle voortbrengselen en van de loonen toont inderdaad duidelijk aan, dat de arbeider geen loonsverhooging genoot in overeenstemming met de prijsverhooging van alle voorwerpen, door hem benoodigd ter voorziening in zijn behoeften. Maar hier stonden verschilleude omstandigheden tegenover, als: de onttrekking van anderhalf millioen personen ten dienste van het leger aan den gewonen arbeid, waardoor aan vele anderen eene gelegenheid werd geopend tot voordeeliger arbeid dan voorheen; de groote sommen door de regeering als bezoldiging en vergoedingen uitbetaald aan de in het leger dienenden, en door dezen ten deele weder an hunne betrekkingen overgemaakt; de groote uitgaven van fabrijkanten en speculanten, plotseling rijk geworden door de rijzing van alle prijzen en door voordeelige leverantien. Dat alles kwam ten voordeele van den 
arbeider, al waren de loonen zelven niet in voldoende mate gestegen. Daarbij moet ook niet uit het oog verloren worden, dat de toestand van den arbeider in Amerika niet was als die van den arbeider in Europa; zijn de verdiensten van den laatste in den regel slechts voldoende ter voorziening in de eerste levensbehoeften, in Amerika was dergelijke armoede onbekend, en onder de vermindering van loon mogt de spaarkracht van den arbeider lijden of daardoor mogt hem de gelegenheid tot overtollige uitgaven ontnomen worden, hierbij bleef het, en zichtbaar was niets veranderd.

De omstandigheden, die na den oorlog verhinderden dat reactie volgde van die abnormale beweging, door den oorlog in het leven geroepen, en die daardoor ook bijdroegen om te verhinderen dat het abnormale dier beweging uitkwam, waren de volgende. Eerstens was door de groote consumtie van het leger, door den buitengewonen uitvoer dien wij reeds behandeld hebben, on nog door eene gedeeltelijke mislukking van den oogst van 1865, de voorraad van alle landbouw-producten tot een uninimum gedaald; on met uitzondering van katoenen en wollen goederen was er evenmin voorraad van gemanufactureerde goederen. De Zuidelijken (eene bevolkig van 12.000 .000 zielen) waren bovendien ontbloot van sohier alle levensbenoodigdheden; maar door hunne terughouding en opstapeling van eene belangrijke hoeveelheid katoen, waren zij bij machte on onmiddelijk en in ruicue mate als koopers voor alle benoodigdheden aan de markt te komen, gelijk blijkt uit het feit, dat de waarde van den uitvoer van katoen van $3,384.000$ gouddollars in 186465 steeg op 199.503 .988 gouddollars in 1865,66 , zijnde het grootste bedrag ooit in een jaar door den uitvoer van katoen gerealiseerd. Uit bedoelde vraag voor allerlei producten ontstond natuurlijk een oven veelzijdig als voordeelig emplooi voor arbeid, en niet het minst was het de landbouw, die daardoor bevorderd en aangemoedigd werd. In de tweede plaats had de Regeering ook nog na den oorlog een aantal uitgaven te doen voor achterstallen van bezoldigingen, vergoedingen en pensioenen, tot afwikkeling van kontrakten enz., betalingen die zich uitstrekten van April 1865 tot Junij 1869 en in ronde cijfers 700.000.000 doll. beliepen. Een groot deel dier gelden werd gebruikt tot den aankoop van allerlei producten, van woningen en gereedschappen enz. enz., het was als het uitzet waarmede de uit den oorlog teruggekeerde soldaten zich weder voor de werken des vredes vestigden, en waardoor niet weinig bijgedragen werd om levendigheid te veroorzaken in de algemeene consumtie en productie. Wederom geldt ook hier de bedenking dat, tegenover 
de middelen aldus aan enkelen verstrekt, do welvaart daardoor verspreid, lasten stonden voor het algemeen die van geen minder belang waren, maar de financieele politiek der regeering was oorzaak, dat de voordeelen dadelijk, de nadeelen eerst later gevoeld werden.

En hiermede zijn wij genaderd tot de behandeling ván een maatregel waartoe de regeering der Ver. Staten na den oorlog besloot, die op zich zelven gevolgen gehad heeft nadeeliger dan alle tot dus verre begane forten, en die tegelijkertijd belet heeft de schadelijko gevolgen van dezen te herstellen. Wij bedoelen het protectie-stelsel à outrance waartoe na den oorlog besloten werd. Het tarief der inkomende rechten dagteekent wel is waar in hoofdzaak van den oorlog, maar daarnaast stond toen de binnenlandsche belasting; en, aangenomen het stelsel dat daarin gevolgd werd, was het buitenlandsch tarief zeker onmisbaar, wilde men niet alle binnenlandsche productie tegenover aanvoer van buitenslands in eenen zeer nadeeligen toestand plaatsen. Dra na den oorlog werd echter aangedrongen op vermindering van belastingen en wel bepaald en uitsluitend van binnenlandsche belasting, en achtereenvolgens in $1866,1867,1868$ en 1869 werd dan ook tot afschaffing en vermindering van binnenlandsche belastingen besloten. Het buitenlandsch tarief werd echter niet alleen gehandhaafd, maar zelfs voor verschillende artikelen verhoogd. Ten deele was zulks niet anders dan het gevolg der financieele politiek tijdens den oorlog. De kolossale schuld, waaronder de Unie gebukt ging, eischte jaarlijks aanzienlijke sommen om in den rentenlast te voorzien en in eene aflossing, die men zooveel mogelijk wenschte te verhaasten ten einde spoedig van dien last bevrijd te zijn. Het was dus noodig dat de regeering in het genot bleef van groote inkomsten; algeheele afschaffing of vermindering der belastingen was onmogelijk en men verlangde het eerst de afschaffing van die belastingen, waarvan de druk zich het meest direkt gevoelen deed. Daarbij kwam nog dat de regeering voor rente en aflossing der schuld goud noodig had: de inkomende rechten moesten in goud betaald worden, op die wijze verkreeg men, zonder bijzondere opoffering, meende men; de middelen om in die rente en aflossing te voorzien. Voorts had, gelijk wij reeds opmerkten, de politiek der re reering gedurende den oorlog tot gevolg gehad eene indirecte bescherming van vele takken van voortbrenging en voornamelijk van de fabrijksnijverheid. $\mathrm{Nu}$ de regeering niet meer door hare inkoopen en leverantiekontrakten die beschorming kon vẹrleenen, en de daaruit vọortgesproten 
opdrijving van prijzen dreigde verstoord to worden, zocht men in bepaalde protectie door het buitenlandsch tarief daarvoor vergoeding; dit was de uitdrukkelijke beweeggrond van verschillende verhoogingen die nog in het tarief gemaakt werden.

Aan grooter dwaling heeft zich wel nooit een verlichte natie schuldig gemaakt dan Amerika door het aannemen van deze financieele en handelspolitiek. De oorsprong van Amerika's welvaart en grootheid is gelegen in de groote natuurlijke rijkdommen van het land, waardoor de bewoners een aantal producten kunnen opleveren onder zoodanige omstandigheden als aan den daaraan te koste gelegden arbeid eene buitengewoon ruime belooning verschaffen. En het veld dat aldus in Amerika ter bearbeiding openligt is zoo ruim dat de productie, die op zoodanige buitengewoon voordeelige wijze plaats kan vinden, slechts hare beperking vindt in den aanvoer der twee onmisbare elementen voor alle productie, de menschelijke werkkracht on het kapitaal dat deze ter hulp moet komen. Maar juist de buitengewoon voordeelige belooning, die de natuurlijke rijkdommen des lands aan allen arbeid ter exploitatie daarvan verzekeren, is oorzaak dat het mogelijk zal zijn eenige voorwerpen, die betrekkelijk veel arbeid vereischen, van andere landen te trekken, waar de arbeid minder ruime belooning vindt of waar door andere omstandigheden, b. v. natuurlijken anleg voor eenigen bepaalden arbeid of langdurige oofening daarin, de omstandigheden voor die voortbrenging gunstiger zijn. Er is geen land, welke ook de verscheidenheid van zijne natuurlijke rijkdommen is, of het zal aldus eenige voorwerpen -op voordeeliger voorwaarden aan andere landen kunnen ontrekken dan ze zelf voortbrengen. En daardoor ook juist, door die verdeeling van arbeid zich uitstrekkende niet alleen binnenslands maar over de geheele wereld, ontstaat de gelegenheid om van de natuurlijke rijkdommen de meest mogelijke vruchten te plukken. Dan geven die natuurlijke rijkdommen aan den bewoner des lands niet. alleen. de voordeelen, die daarvan het onmiddelijk gevolg zijn, maar hij wordt daardoor in staat gesteld ook te beschikken over de voortbrengselen van andere landen; de rijke belooning, die zijn arbeid vindt, geeft hem aldus niet alleen een groote koopkracht in zijn eigen land, maar over de geheele wereld.

En wat is nu het zoeken van de protectionnisten in Amerika? het is om ook aan die voortbrenging, die niet door de natuurlijke rijkdommen des lands buitengewone voordeelen afwerpt, of die dit slechts in mindere mate doet, toch gelijke voordeelen to verzekeren. Door hooge inkomende rechten moet de prijs van zoodanige voor- 
werpen opgedreven worden tot zulk een hoogte dat de hinnenlandsche producent met den importeur de concurrentie kan volhouden. Maar wie betaalt het gelach? niemand anders als de consument, dat is het algemeen. En waarop komt nu eigenlijk de geheele manoeuver neer? hierop, dat voor zoover het de consumtie of de aanschaffing ter bearbeiding van dergelijke beschermde artikelen geldt, do natuurlijke voordeelen die het land aanbiedt voor den producent in het algemeen verloren gaan, want in gelijke mate als zijn werk hem een ruime belooning verschaft moet hij zich nu ook een grootere opoffering getroosten om zich dergelijke voorwerpen aan te schaffen. Met even zooveel als de beschermde productie bevoordeeld wordt, wordt de productie in het algemeen benadeeld. De loonen en verdiensten mogen dezelfde blijven, hunne nuttigheid, hunne betrekkelijke waarde worden verminderd. In plaats dus van teweeg te brengen eene uitbreiding van het veld, waarop met buitengewone voordeelen gearbeid kan worden, wordt aan die voordeelen in het algemeen afbreuk gedaan. Bovendien worden nog aan de productie, die op zich zelve de buitengewone voordeelen afwerpt, de werkkrachten en het.kapitaal onttrokken die vereischt worden voor de onnutte productie, en zoodoende wordt niet alleen de betrekkelijke waarde der voordeelige productie, maar ook die productie zelve verminderd. Onder de directe gevolgen van het protectiestelsel behoort dan ook, dat de mogelijkheid tot het verrichten van exporten er door aangetast wordt, dat deze er noodwendig onder moeten lijden, hetgeen juist tegenovergesteld is aan hetgeen mon in Amerika zocht, namelijk de vermindering der importen. Een ander onmisbaar resultaat voor Amerika moest wezen de tegenwerking der landverhuizing daarheen; immers naarmate de arbeid daar minder voordeelig wordt, de betrekkelijke waarde der loonen on verdiensten er afneemt, wordt de prikkel tot landverhuizing verminderd.

Dat onder zulke omstandigheden aan de ontwikkeling van de welvaart, die men na den oorlog verwachtte, groote afbreuk is gedaan, kan niet bevreemden.

Onze ruimte laat ons niet toe de gevolgen van de gewraakte maatregelen in bijzonderheden na te gaan. Bij één resultaat moeten wij echter stilstaan, namelijk bij de verhouding tusschen de exporten en importen die daardoor bestendigd is, want daarin ligt voor een goed deel de oorzaak der crisis, die in 1873 uitgebroken is en waaronder het land zoo langen tijd gebukt is gegaan. $\mathrm{W}_{\mathrm{ij}}$ zeggen intusschen met opzet dat daardoor die verhouding is bestendigd, niet veroorzaakt; de oorzaak was van ouderen datum, 
Reeds de oorlog had eene anzienlijke vermindering van Amerika's exporten te weeg gebracht; in de eerste plaats door het ophouden der uitvoeren van het zuiden en met name van het stapel-product, het katoen. Maar ook de afbreuk aan de algemeene productie door den oorlog gedaan, de buitengewone consumtie daardoor ten andere veroorzaakt, daarbij de financieele politiek door de regeering gedurende den oorlog gevolgd, hadden - ook ondanks den buitengewonen uitvoer van tarwe, reeds gemeld - in dezelfde richting gewerkt. Al ware het alleen geweest om het aldus verbroken evenwicht to herstellen, zoo had na het herstel van den vrede, de zorg der regeering moeten zijn door een vrijhandelspolitiek de productie en daardoor de vitvoeren te bevorderen; zooals wij gezien hebben, vond echter het tegenovergestelde plaats. $\mathrm{W}_{\mathrm{ij}}$ vestigen nu nog eens de aandacht op de ejjers van in- en uitvoer, daartoe gebruik makende van staten, aangevende de invoeren na aftrek van de weder-uitvoeren en de uitvoeren van uitsluitend binnenlandsche producten, voorts de uitvoeren, herleid tot de goud-waarde. Wij vinden dan:

\begin{tabular}{|c|c|c|c|c|}
\hline $1850-51$ & $\begin{array}{c}\text { Ynvoeren } \\
194.500 .000\end{array}$ & doll. & $\begin{array}{c}\text { Uitvoeren } \\
196.600 .000\end{array}$ & \\
\hline $1851-52$ & 195.600 .000 & $n$ & 193.300 .000 & \\
\hline $1852-53$ & 250.400 .000 & $n$ & 213.400 .000 & $n$ \\
\hline $1853-54$ & 280.800 .000 & $\pi$ & 253.300 .000 & \\
\hline $1854-55$ & 233.000 .000 & $\eta$ & 246.700 .000 & \\
\hline $1855-56$ & 298.200 .000 & $\pi$ & 310.500 .000 & \\
\hline $1856-57$ & 336.900 .000 & $n$ & 338.900 .000 & \\
\hline $1857-58$ & 251.700 .000 & $n$ & 293.700 .000 & \\
\hline $1858-59$ & 317.800 .000 & $n$ & 335.800 .000 & n \\
\hline $1859-60$ & 335.200 .000 & $n$ & 373.100 .000 & n \\
\hline $1860-61$ & 332.000 .000 & $n$ & 382.800 .000 & n \\
\hline Totaal in 11 jaar & $3, \overline{026.100 .000}$ & $n$ & $\begin{array}{l}3, \overline{138.100 .000} \\
3,026.100 .000\end{array}$ & \\
\hline \multicolumn{3}{|c|}{ Moerder bedrag der uitvoeren } & 112.000 .000 & \\
\hline $1861-62$ & 261.300 .000 & doll. & $2 1 3 2 \longdiv { 2 0 0 . 0 0 0 }$ & doil. \\
\hline $1862-63$ & 226.800 .000 & $n$ & 240.400 .000 & \\
\hline $1863-64$ & 309.300 .000 & $n$ & 241.900 .000 & \\
\hline $1864-65$ & 216.400 .000 & $n$ & 196.200 .000 & $n$ \\
\hline $1865-66$ & 430.700 .000 & $\pi$ & 417.100 .000 & n \\
\hline $1866-67$ & 391.100 .000 & n & 334.300 .000 & n \\
\hline $1867-68$ & 351.200 .000 & 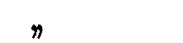 & 352.700 .000 & n \\
\hline $1868-69$ & $412.200 . \cap 00$ & $n$ & 318.000 .000 & $\eta$ \\
\hline
\end{tabular}




\begin{tabular}{|c|c|c|c|c|}
\hline $1869-70$ & 431.900 .000 & doll. & 420.500 .000 & doll \\
\hline $1870-71$ & 513.100 .000 & $n$ & 513.000 .000 & \\
\hline $1871-72$ & 617.600 .000 & $n$ & 501.100 .000 & $n$ \\
\hline \multirow[t]{2}{*}{ Totaal in 11 jaar } & $4,161.600 .000$ & $n$ & $3,748.400 .000$ & \\
\hline & $3,748.400 .000$ & $n$ & & \\
\hline $\begin{array}{l}\text { eerder bedrag der } \\
\text { invoeren }\end{array}$ & 413.200 .000 & $n$ & & \\
\hline
\end{tabular}
oorlog, zoo is in doorslag de waarde der invoeren 44.000.000 doll. per jaar meer dan die der uitvoeren. Hierbij moet nu in aanmerking genomen worden dat Amerika na den oorlog voor een aanzienlijk bedrag de schuldenaar was van Europa. Men berekent dat einde 1869 de navolgende Amerikaansche fondsen in Europa gehouden werden :

Obligaties der Ver. Staten . . . . . . . . 1,000.000.000 doll. $n \quad$ van bijzondere Staten . . . . . 100.000.000 n

Spoorwegfondsen ............ 243.000:000

Stedelijke oblig., aand. en oblig. van Mijnen enz. 22.500 .000 n Hypotheken op vast goed . . . . . . . 25.000.000 n

Terwijl verder Amerika in schuld was voor tijdelijke plaatsingen . . . . . . . 75.000.000 n

en de hieruit voortvloeiende jaarlijksche renteschuld wondt begroot op . . . . . . 80.000.0ne voorts had (destijds) Amerika jaarlijks voor vracht aan vreemde schepen te betalen ... 24.000.000 n en te remitteeren voor de verteringen van Amerikanen in den vreemde........ 25.010n.000, De uitwoeren hadden dus destijds 129.000.000 meer moeten bedragen dan de invoeren om de jaarlijksche rekening met het buitenland te doen sluiten, en wij hebben gezien dat integendeel een aanzienlijk saldo aan de andere zijde gevonden wordt.

Het evenwicht werd hersteld door voortdurende plaatsing van Amerikaansche fondsen in Europa: in de eerste plaats was Europa in het algemeen nog altoos kooper van obligatien der Ver. Staten en van bjjzondere staten, maar voornamelijk waren het spoorwegfondsen die genomen werden.

Zoodra echter Europa zoude ophouden dergelijke fondsen op te nemen of ook maar daarin eene belangrijke vermindering zoụde brengen, konden de gevolgen van dien stand van zaken niet uit- 


\section{5}

blijven. Een ommekeer in de verhouding tusschen de in- en uitvoeren moest dan tot stand komen en natuurlijk zou deze alleen mogelijk worden door verandering in de verhouding der prijzen tusschen Amerika en Europa. En voor zooverre dus geene prijsverhoogingen in Europa zouden ontstaan, moest eene algemeene prijsverlaging in Amerika plaats vinden. Wat dergelijke prijsverlaging voor handel en nijverheid beteekent on welke daarvan de noodwendige gevolgen zijn, behoeven wij niet te herinneren.

Geen andere is in werkelijkheid de loop van zaken geweest; en deze toestand is dan ook de oorzaak geweest dat, toen in 1873 uit het wantrouwen dat zich voor de spoorwegfondsen begon te vertoonen een spoorweg-crisis ontstond, deze zich tevens uitbreidde tot een algemeene handels- en nijverheids-crisis, en daardoor zijn de gevolgen van die crisis zoo algemeen en gedurende zoo langen tijd gevoeld.

De spoorweg-crisis is veroorzaakt door dat de aanleg van nieuwe spoorwegen te groote en te schielijke ontwikkeling had verkregen. De noodlottige gevolgen daarvan waren van tweeërlei aarḍ.

De uitkomst heeft bewezen dat de uitbreiding van het spoorwegnet de behoeften van het verkeer overtrof. Aan Poor's Manuals voor $1874-75$ en $1875-76$ ontleenen wij de opgaven op de volgende blz. betreffende den stand van zaken in 1873 en 1874.

Wij zullen deze resultaten vergelijken met die van 1871 , als medegedeeld op pag. 304; men zal bemerken dat er eenig verschil bestaat tusschen de groepeeringen van Giffen en Poor, verklaarbaar uit het feit dat verscheidene lijnen door meer dan één staat loopen, hetgeen gemakkelijk tot zoodanig verschil aanleiding kan geven. De spoorwegen in de Pacific-staten, waaronder Poor de Central pacific opneemt, toonen tengevolge der aanhoudende vermeerdering van het vervoer op dien weg een ongestoorde verbetering van resultaten aan; ook op de spoorwegen in de Nieuw-Engeland Staten is blijvende progressie van inkomsten, maar het mijlental van deze is dan ook niet noemenswaard toegenomen. Bij de overige spoorwegen vinden wij echter de navolgende resultaten. (Wij nemen de wegen in de Midden en Westelijke onder één hoofd, daar klaarblijkelijk ten opzichte van deze Giffen en Poor, eene geheel verschillende scheiding gemaakt hebben). 

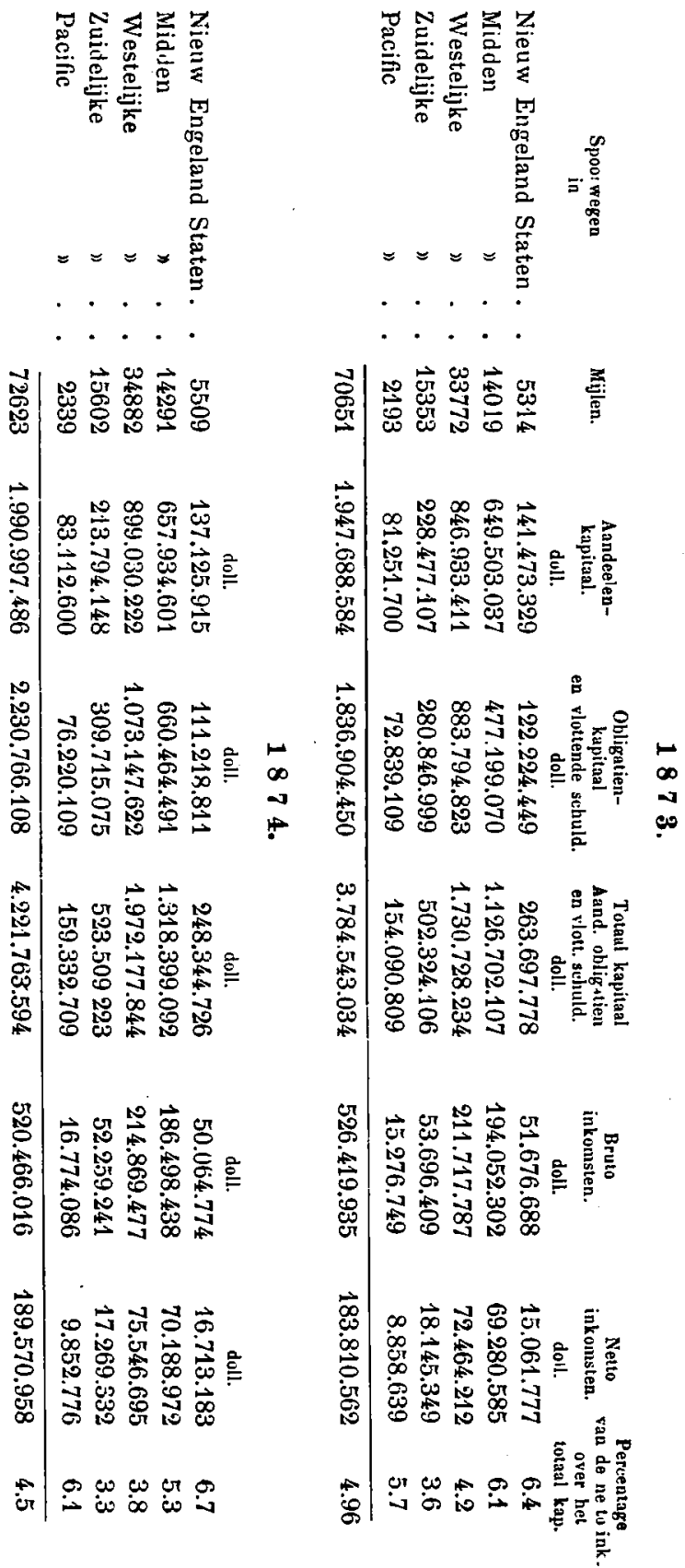


\section{7}
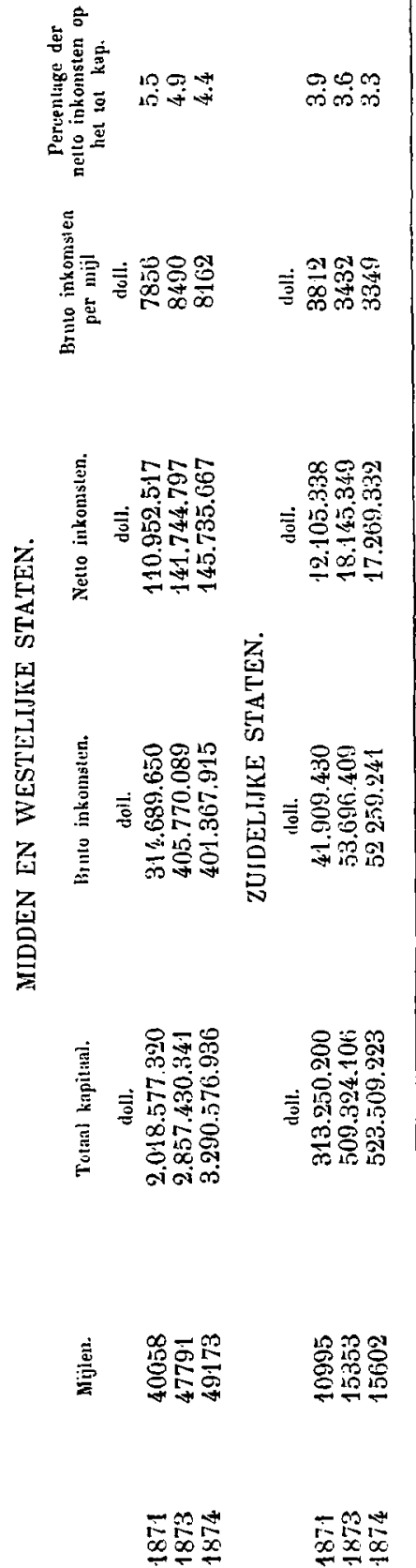

Econ. 1877.
Op de spoorwegen in de Midden en Westelijke Staten waren aldus de bruto-ontvangsten per mijl tot aan de crisis van 1873 wel in gelijke mate, zelfs nog meer toegenomen dan het mijlental; maar het eindresultaat, de netto-inkomsten over het kapitaal vertoonen reeds een gevoeligen achteruitgang; tegenover de verhoogde kosten van aanleg en onderhoud heeft geen evenredige vrachtverhooging ingevoerd kunnen worden; er is te veel concurrentie ontstaan om het verkeer even winstgevend te doen zijn als vroeger. En na de crisis is dadelijk de achteruitgang der resultaten, en thans in het algemeen, zeer sterk; een bewijs dat, toen althans, het spoorwegnet tegenover de verkeers-behoeften te groote uitbreiding had verkregen. $O p$ de zuidelijke lijnen is de achteruitgang van zaken reeds van 1871 op 1873 in ieder opzicht aanzienlijk; daartoe hadden bijzondere omstandigheden medegewerkt, waarop wij nader terugkomen.

Het tweede noodlottige gevolg, van de te groote en snelle uitbreiding van het spoorwegnet was, als gezegd, van anderen aard, en dit was tevens van nog wijder strekkende beteekenis; daardoor vooral werd bijgedragen tot het ontstaan der erisis van 1873 , die, op hare beurt weder reagerende op het spoorwegverkeer, het nadeel zooveel to meer deed gevoelen; wij bedoelen de vastlegging in zoo korten tijd van een zoo aanzienlijk kapitaal. als voor den spoorwegaanleg vereischt werd. 
Volgens Poor waren in 18694720 s mijlen spoorweg in exploitatie, waarvan de kostende prijs (totaal kapitaal van aandeelen, obligatien en verdere schulden) 2.000.000.000 doll. bedroeg; voor 1871 vonden wij deze bedragen:

$$
\begin{aligned}
& \text { Mijlen 58402 Kapitaal 2.820.294.310 doll. } \\
& \text { voor } 1873 \text { "70651 " 3.784.543.034 " }
\end{aligned}
$$

uitmakende van $1869-1873$, d. i. in 4 jaar, ecn kapitaalsvermeerdering van, in ronde som, 1780 millioen dollar; voor ongeveer $2 / 3$ zal die kapitaalsvermeerdering door obligatien vertegenwoordigd zijn d. i. 1.200.0no.0vo doll. stelle à $70 \mathrm{pCt}$. is reëel kapitaal

840.000 .000 doll.

nemen wij nu voor ongeveer 600 millinen doll.

aandeelen kapitaal slechts reëel kapitaal . . 160.000 .000 "

$$
\text { zoo vinden wij . . . 1.000.000.000 doll. }
$$

reëel kapitaal van $1869-1873$ aan de spoorwegen te koste gelegd. Hiervan moet afyetrokken worden het bedrag door Europa gefourneerd; volgens de Comm \& Fin. Chronicle werden in 1874 in Europa gehouden nominaal kapitaal obligatien . . . . . 375.000.000) doll.

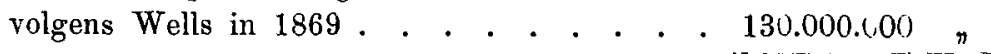
plaatsing 1869-1874 . . . . . . . . 245.000.000 doll. à $70 \mathrm{pCt}$. . 171.500 .000 doll. voegen wij daarbij voor diverse aandeelen . . 28.500 .000 . wordt . . 200.000 .000 doll. blijft door Amerika zelf aan zijn spoorwegen in gezegde vier jaar $(1869-1873)$ te koste gelegd 800.100 .000 doll. en daar zoude dan nog bijgevoegd moeten worden, het kapitaal vereischt voor de nijverheid die met den spoorwegaanleg in verband staat en daardoor gevoed wordt; het is waarschijnlijk dat dit meer is dan het kapitaal door Europa gefourneerd. Houden wij ons echter aan het eijfer van 800 millioen, zegge 200 millioen per jaar. Dit bedrag is reeds belangrijk genoeg; en vooral moet een dergelijke overgang van vlottend in vast kapitaal zieh sterk hebben doen gevoelen, daar - gelijk wij gezien hebben - tegelijkertijd aanzienlijke kapitalen door het beschermend tarief, ter wille van een aantal kunstmatig in het leven geroepen of gehouden industriën, aan de natuurlijke productie werden onttrokken, en dat alles, terwijl voor een goed deel de kosten van den oorlog nog betaald, de verwoestingen door dezen aangericht nog hersteld, de leemten door dezen veroorzaakt nog pangevuld moeston worden. 
Beschouwt men den toestand in Amerika onder dit licht, zoo kan het geen verwondering mcer baren, dat aan de verwachtingen van de eerste jaren na den oorlog niet beantwoord, maar integendeel op de groote beweging van die jaren eene sterke reactio gevolgd is; het blijkt nu dat er toen veel overspanning in het werk was, en de ontspanning is zooveel te sterker geweest, daar men tot verkeerde maatregelen was overgegaan.

Maar had dit alles niet voorzien kunnen en moeten worden?

Wanneer men leest de beschouwingen door Wells op het einde van 1871 en vooral die door prof. J. E. Cairnes in 1873 over de Amerikaansche toestanden geleverd - de eerste in zijn studie genaamd ${ }_{n}$ The recent financial, industrial and commercial experiences of the United States, a curious chapter in politico-economic history", voorkomende in de Cobden Club Essays van 1871-72; de tweede in zijn werk getiteld "Some leading principles of political economy"; aan welke beide geschriften wij verschillende der hier medegedeelde bijzonderheden en beschouwingen ontleend hebben wanneer, zeggen wij, men deze studiën leest, dan wordt men getroffen door de logica der verschijnselen in de economische geschiedenis van de Ver. Staten in de laatste jaren, en men wordt overtuigd dat de bestaande oorzaken niet anders dan de verkregen gevolgen konden hebben. Maar het is nu eenmaal cle treurige waarheid, dat economische verschijnselen in hunne beteekenis, op het oogenblik dat ze zich voordoen, niet zoo gemakkelijk te onderscheiden zijn als later door den denker, die in de rust van zijn studeerkamer de gebeurtenissen voor de oogen van zijn geest weder voorbij laat trekken. Wij bedoelen daarmede natuurlijk niet, dat Wells en Cairnes in 1871 en 1873 eerst tot de ontdekking konden komen, dat een protectionistisch tarief voor Amerika evenmin voordeelig is als voor welk land ook (en hoevelen intusschen die hiervan nog niet doordrongen zijn); maar er zijn altoos in een land zoovelerlei omstandigheden in het spel, die op de welvaart en de ontwikkeling invloed uitoefenen, dat het dikwijls zeer moeilijk valt te beoordeelen, wat van die gezamenlijke oorzaken het eindresultaat zal zijn. Wells zelf had in zijn rapport over i 869 nog geschreven: "In short, the experience of auother year reaffirms the principle before announced, that the progress and growth of the country through its elements of vitality, viz., great national resources and an inherent spirit of energy and enterprise in the people, are in a great degree independant of legislation, and of the empoverishment and disorder which the occurence of a long 


\section{(3) 30}

War has neeessarily occasioned". En prof. Caimnes wijst ook uitdrukkelijk op de buitengewone oorzaken van welvaart en toenemenden bloei, die in Amerika aangetroffen werden en die het moeilijk maakten de gevolgen van de handelspolitiek gewaar te worden, daar tengevolge van die oorzaken zoovele resultaten in strijd waren met hetgeen men van die handelspolitiek moest verwachten. Hoeveel waarde werd gehecht aan de gunstige omstandigheden, waaronder Amerika verkeerde, blijkt nog uit de voorrede van de Cobden-club bij den door haar in 1870 uitgegeven herdruk van het rapport over 1869 van Wells; wij lezen daar toch „with such advantages and such laws in respect of land, it must be admitted that, with all its extravagance and excesses, the American people can better afford their present false and costly system of industrial monopoly, than the English people can afford their system of taxation".

Wat de spoorweg-quaestie in het bijzonder aangaat, zoo hebben wij reeds vermeld, welke uitbreiding Poor in 1870 voor de naaste toekomst door de omstandigheden gewettigd achtte. Wij stellen nu tegenover elkander het toenmalige mijlental, Poor's begrooting eener gewenschte uitbreiding en de in 1873 verkregen uitbreiding:

Nieuw-England Staten

Mijlen in 1870 Uitbreiding door Mijlen in 1873

Midden in operatie.

Poor gewenscht.

in operatie.

$\begin{array}{lllll}\text { Westelijke } & n & 19765 & 54000 & 33772 \\ \text { Zuidelijke } & \eta & 11272 & 35000 & 15353\end{array}$

Er bleef dus nog een groote afstand tusschen hetgeen verricht was en hetgeen volgens Poor's schatting verricht moest worden, toen de crisis van 1873 uitbrak.

Het was inderdaad niet voor 1872 à 1873 dat zich eene meening begon te vormen, dat men zich aan "overdoing" in zake spoorweg-aanleg schuldig maakte. Wij vinden daarvan gewag gemaakt in de "Financial review" over 1872 van "The Commercial and Financial Chronicle". De schrijver meldt, dat in de laatste maanden vertraging is gekomen in den anbouw van nieuwe spoorwegen. Aan de schaarschte van het geld, die eenige maanden lang zeer groot was, alsmede aan eenen sedert Julij 1872 ingetreden stilstand in de opname der spoorwegfondsen door Europa, wordt zulks toegeschreven. Schr. voegt daarbij, dat volgens sommigen er werkelijk te veel gedaan werd, vooral de invloed daarvan op de geldmarkt wordt geducht (in dit artikel wordt gesproken van een kapitaal van $400 \mathrm{~mm}$. ds. dat laatstelijk jaarlijks door de spoorwegen geabsor- 
beerd zou zijn). Iets mag daarvan aan zijn, ofschoon men niet vergeten moet dat iedere spoorweg ook weder een bron is van nieuwe rijkdommen; men mag aannemen dat door de bestaande spoorwegen meer kapitaalsbesparing en -vorming plaats vindt dan wat voor den aanleg van nieuwe wegen verlangd wordt. Intusschen het is mogelijk dat in de laatste jaren to veel vlottend kapitaal aan de geldmarkt onttrokken is, en het is daarom maar goed dat er eenige vertraging komt in de beweging. Eone voorbarige beteugeling is beter, dan dat men nog eenige jaren op dezelfde wijze zou doorgaan, dan zoutle het kwaad minder gemakkelijk te verhelpen kunnen zijn.

Zelfs een blad als de C. en F. Chronicle achtte dus in het begin van 1873 vertraging in den anbouw nog niet door de omstandigheden vereischt, de beteugeling kon geen kwaad ter vermijding van overdrijving, maar mocht destijds toch voorbariy genoemd worden. Nog opmerkelijker is het volgende. In een hoofdartikel in de Engelsche "Economist" dd. 26 December 1874 wordt Amerika's toestand behandeld en de gevolgen nagegaan van de crisis van 1873 en daar lezen wij: „We refer especially to the immense construction of railways in America, namely in the Western States, during recent years." En na de mededeeling van eenige eijfers volgt dan "We fear we did not appreciate the ominous importance of these figures at the time". Ook de altoos zoo voorzichtige Engelsehe "Economist" die zich toch warrlijk niet licht laat medeslepen, moet alzoo in 1874 erkennen zich vroeger bedrogen to hebben in hare appreciatiën van de ontwikkeling der spoorwegen in Amerika. In gezegd artikel wordt verder gewezen op eene omstandigheid die toen door de ervaring aan het licht gekomen zou zijn, namelijk dat de landbouw-productie der wereld in de laatste jaren grooter zou zijn geweest dan de behoefte. De Economist noemt ook dit onder de redenen, waardoor de ontwikkeling van Amerika niet aan de verwachtingen beantwoord heeft, en schrijft het bepaald daaraan toe dat in het bijzonder de gang van zaken in het Westen zooveel teleurstelling heeft gegeven; \#Hence when the western railways were built, the population not only did not follow them as had been calculated, but perhaps did not follow to the extent which it might have been reasonable to calculate on, if the agriculture of the world had not outgrown the demand for its products."

Met het oog op de ook hier ondervonden teleurstellingen in landbouw-ondernemingen in het Westen heeft dergelijke beschouwing dubbele waarde.

$W_{i j}$ moeten nu nog op eenige verdere omstandigheden wijzen, 
die er toe bijgedragen hebben, om de ontwikkeling der stoffelijke welvaart in Amerika tegen te werken.

Wij hebben dan in de eerste plaats te noemen de handhaving der papieren-geld circulatie. Het was niet te verwachten, dat tien jaar na het einde van den oorlog de toestand dienaangaande nog letterlijk onveranderd zou zijn; dat een zoo praktisch en zoo verlicht volk zoolang uit zoude stellen, om door eene betrekkelijk geringe opoffering zich te onttrekken aan de dagelijks wederkeerende verliezen, die het gevolg zijn van het ontbreken van eenen vasten grondslag voor alle handelstransactiën. Het was zulks omstreeks 1869-70 te minder, daar dra na den oorlog dit eene "question brulante" was geworden, en de verkiezing van President Grant immers de beteekenis had, dat men eerlijke en volledige nakoming van alle verplichtingen van den Staat wenschte, waaronder ook spoedige terugbetaling der rentelooze schuld.

Niet minder dan ten opzichte der papieren-geld quaestie was het ten opzichte van den toestand van het Zuiden, dat men van Grants optreden de beste verwachtingen had, maar vooral geen mindere teleurstelling volgde ook hier. "A condition of peace and security" had The Nation geschreven, zou Grants regeering aan het Zuiden brengen; ook in de constituties, door de Zuidelijke Staten angenomen, mocht men een waarborg gelegen achten voor hun vernieuwden bloei en vreedzame ontwikkeling. In een hoofdartikel van The Nation dd. 21 Mei 1868 werden die constituties als een voorbeeld aan de Noordelijke Staten voorgehouden, vooral die van Alabama en Florida werden hoogelijk geroemd. Maar de ongelukkige politiek, die weldra in Washington gevolgd werd met betrekking tot het Zuiden en waardoor de macht aldaar in handen werd gespeeld van de te wel bekende "Carpet-baggers" veroorzaakte een geheelen ommekeer van zaken.

Opmerkelijk is ten opzichte dezer quaestie een artikel in de Engelsche "Economist” over Florida; het is een uit een Amerikaansch blad overgenomen brief uit St. Augustine, dd. 15 Februarij 1873, en de Economist voegt er bij, dat dit rapport van groote beteekenis is, komende van eene zijde die van geen zuidelijke sympathiën verdacht is; het stuk is voor ons to meer belangrijk daar het juist handelt over eenen staat, die hier zooveel teleurstelling heeft veroorzaakt. De schrijver roemt zeer de buitengewone vruchtbaarheid van het land, en verhaalt dat in de eerste jaren na den oorlog een aantal Noordelijke kapitalisten zich daar kwamen vestigen om het land in cultuur te brengen, hoe de handel daardoor toenam, de 
steden en onder deze vooral Jacksonville hunne bevolking schielijk zagen vermeerderen, allerwege welvaart begon te herleven en de Staat de schoonste toekomst scheen te gemoet te gaan. Maar zeer enkele jaren slechts duurde dit, en honderde families verlieten weder hunne plantages en woningen, afgeschrikt wordende door het slechte regeeringsbeleid, en hun geld torugtrekkende uit een land, waar veel van hen verlangd en weinig voor hen gedaan werd. Uit Georgia en South Caroline, voegt de schr. er bij, komen soortgelijke verhalen tot hem, overal in de Zuidelijke Staten schijnt dit de stand van zaken te zijn.

Dergelijke mededeelingen geven de verklaring van de volkomen teleurstelling van alle verwachtingen, die hun grondslag vonden in hetgeon men in de eerste jaren na den oorlog in het Zuiden opmerkte; ze behelzen tevens de verklaring van het vermelde verschijnsel, dat de achteruitgang der zuidelijke spoorwegen reeds van 1871 dagteekent.

Nog in een derde opzicht werd van Grant's verkiezing de beste invloed verwacht, te weten ter hervorming van de openbare dienst en ter zuivering van het administratieve personeel. Om aantetoonen hoezeer hieromtrent goede verwachting bestond, veroorloven wij ons nog eens eene aanhaling uit "The Nation". Wij lezen daar "Grant is not a regular politician. He will be the first President the country has had for many a long day on whom old party doctrines as to "spoils" and "claims" will have no influence. He has been bred in a very different and a very much better school, a school in which honor and merit are still words that mean something, and that stand for forces in human affairs. He has shown, too, in his administration of the army, that he knows a good man when he sees him, and that as soon as he sees him he clasps to him with hooks of steel. $\mathrm{He}$ is by education and temperament the foe of jobbers, intriguers, and blatterers, and will undoubtedly apply to the eivil service, in so far as he can, the rules of selectiou and promotion by the aid of which he has given such splendid illustration to American military annals." Zoo ooit een uitkomst onbevredigend is geweest dan is het in dit geval, en het ware voor Grant's reputatie, van zich door eerlijke ambtenaren te weten omringen, zeker wenschelijk geweest dat hij nooit President was geworden. Het aangehaalde artikel maakt thans haast het effect van uit ironie geschreven te zijn. Nooit toch hoorde men van zooveel corruptie eu misbruik van macht in de regeeringskringen als in de laatste jaren; nooit was gunstbetoon ten bate van particuliero 
belangen en ten nadeele van het algemeen belang meer aan de orde, nooit wist men ook beter de rechterlijke macht dienstbaar te maken aan bijzondere oogmerken, getuige b. v. de vervanging van verschillende rechters in de „Granger's-movement" geschiedenis, of zoovele uitspraken in zake staatsverplichtingen, enz. in het Zuiden. Op meer dan eene wijze hebben ongelukkiglijk de Europeesche geldgevers in Amerikaansche zaken daaronder geleden.

Zullen wij niet al te wijdloopig worden dan moeten wij thans echter van dit onderwerp afstappen. Wij dienen daarentegen nog enkele bijzonderheden te behandelen in zake de spoorweg-aangelegenheden.

In de voorgaande behandeling van den loop van zaken hebben wij ons slechts bezig gehouden met de resultaten van het spoorwegverkeer in het algemeen, en het zal de aandacht niet ontgaan zijn, dat die algemeene cijfers niet getuigen van zoo grooten achteruitgang, als men zoude moeten veronderstellen op grond van de vele stakingen van rentebetaling, waaronder de Europeesche geldgevers geleden hebben. De reden van dit verschil is niet, zoo als men wel eens betoogd heeft, dat de slechte fondsen hierheen gekomen, de goede in Amerika gehouden zijjn. Enkele cijfers zullen spoedig de onjuistheid eener dergelijke bewering aantoonen. In "The Financial Review" over 1875 door de C. en F. Chronicle uitgegeven vinden de noodlijdende spoorwegen eene speciale en zeer uitvoerige behandeling. Volgens den schrijver van dat overzicht bedroeg toen het obligatien-kapitaal van alle Amerikaansche spoorwegen waarop de rentebetaling gestaakt was $\mathbf{7 8 9 . 3 6 7 . 6 6 5}$ doll.; daaronder echter niet begrepen de obligatien, die, nooit publiek uitgegeven, bij ondernemers, contractanten of bankiers in portefeuille gebleven waren, maar wel die waaromtrent reeds, langs gerechtelijken weg of door minnelijke schikking, regeling plaats vond. Het totale bedrag van spoorweg-obligatien op 1 Januarij 1875 wordt door Poor opgegeven op 2.000.000.000 doll. Het bedrag van 2.230.776.108 doll. gemeld in onzen staat, pag. 316 , omvat ook de vlottende schulden, income bonds enz., die afgetrokken dienen te worden.

Wij vinden alzoo dat de noodlijdend geworden obligatien bijkans $40 \mathrm{pCt}$. van het totaal bedrag uitmaken. Om eene juiste vergelijking te maken moet echter als het totaal bedrag der obligatien niet genomen worden dat wat in het geheel bestaat, maar het kapitaal dat gevormd is sedert de Europeesche markten die fondsen opgenomen hebben, dus sedert 1866-67; het bedrag van 2.000.000.000 doll. moet alzoo verminderd worden met minstens 
660.000 .000 , aannemende 40 pCt. van het toenmaals bestaande totale kapitaal der spoorwegen, wijl juiste opgaaf ontbreekt. Wij vinden alsdan dat het bedrag der noodlijdend geworden obligatien bijkans $60 \mathrm{pCt}$. van het totaal beloopt. Ten opzichte der vraag die ons bezig houdt, zouden ook wel degelijk de nog onuitgegeven obligation in aanmerking genomen moeten worden, daar die op eene enkele uitzondering na geheel voor Amerikaansche rekening komen. Het bedrag van deze is niet bekend maar moet vrij aanzienlijk zijn, als af te leiden valt uit het aantal faillissementen dat juist door dergelijk bezit reroorzaakt is; daarvoor slechts 60 à 80 $\mathrm{mm}$. doll. aannemende klimt do vermelde percentage tot 65 . Onder de in 1875 in Nederland gehouden 116.000 .000 doll. obligatien waren 64.000 .000 doll. waarop staking van rentebetaling had plaats gevonden; aldus vinden wij in Nederland, tegenover de totale verhouding van 60 of 65 pCt., slechts 55 pCt. Het zijn alzoo niet de Nederlandsche geldgevers alleen, die te klagen hebben over meer stakingen van rentebetaling, dan op den eersten aanblik door den algemeenen achteruitgang van het verkeer gewettigd schijnt; maar wij hebben te doen met een algemeen verschijnsel, en de oorzaak daarvan is in werkelijkheid niet ver te zoeken. Die oorzaak is geen andere dan de financieele basis der Amerikansche spoorwegen.

Bij de groote inkomsten, die de spoorwegen in Amerika over het geheel spoedig genoten, was het gevaar, ontstaande uit een, in verhouding tot den totalen en werkelijk kostenden prijs, hoog en somwijlen zelfs zeer hoog obligatienkapitaal, vroeger gebleken schier niet te bestaan; maar onder den invloed van den loop van zaken in de laatste jaren is de toestand een geheel andere geworden. Ook bij den best gelegen en meest belovenden spoorweg zal het verkeer zich slechts geleidelijk en in ieder geval eerst na voltooiing van den weg volledig kunnen ontwikkelen. Tengevolge der groote concurrentie van nieuwe lijnen, konden deze nu minder gemakkelijk en minder spoedig dan voorzien was, deze eerste ontwikkelingsphase te boven komen; menige spoorweg-maatschappij zag zich daardoor verplicht vlottende schuld aantegaan ter dekking van het deficit van de eerste jaren, en toen door de crisis van 1873 aan dergelijke geldopnemingen een einde werd gemaakt, terwijl tevens de behoefte daaraau zooveel te grooter en te algemeener werd, en ook nog door de naweeën van die crisis de hoop verijdeld werd, dat aan die aanvankelijk ondervonden moeilijkheden spoedig een einde zoude komen, toen was het dat een aantal maatschappijen successivelijk de rentebetaling op hare leeningen moesten 
staken. In nog grooter moeilijkheden werden die maatschappijen gebracht, wier lijnen nog niet voltooid waren, en die gerekend hadden op eene doorgaande plaatsing hunner leeningen om in de aanlegkosten te voorzien, daar deze nu, tegenover de bestaande schulden, slechts een deel van een spoorweg bezaten, dat in vele gevallen alleen door voltooiing op waarde kon komen en toch aan die voltooiing nu niet te denken viel.

Zoo wordt het verklaard dat de nieuwere maatschappijen zoo onvergelijkelijk veel meer onder de tijdsomstandigheden geleden hebben dan de ouderen; diegenen onder dezen, die door uitbreiding hunner lijnen aan de algemeene beweging hadden deelgenomon, moesten ook wel hun deel in de teleurstellingen dragen, maar zij vonden in het gevestigd verkeer op de oude lijnen, dat door vele nieuwe lijnen zelfs zeer gevoed en bevorderd werd, de middelen om in de nieuw op zich genomen verplichtingen van rentebetaling te voorzien, zij het dan ook ten koste der dividenden, die humne aandeelhouders te voren gewoon waren te genieten en thans moesten derven.

Ontegenzeggelijk waren er bovendien onder de nieuwe ondernemingen, die geen voldoende raison d'être hadden, of waarbij althans, als door de uitkomst gebleken is, met groote overdrijving gerekend werd op den voortduur van eene ontwikkeling en bloei, die nog onvoldoende verzekerd waren; en dat er zelfs grond is te vermoeden, dat er onder de ontwerpers van enkele zaken ook wel eens misbruik gemaakt is van de heerschende verwachtingen in Amerika en van de bestaande impressies en stemming in Europa, wie zal het absoluut durven ontkennen? Misbruik is er zeker ook in meer dan eene zaak gemaakt van de genegotieerde gelden en een min of meer belangrijk deel daarvan aan de bestemming onttrokken, of wel is door verkeerde administratie deze of gene zaak gebracht in moeilijkheden, waarvoor anders geen reden bestaan had.

Eindelijk is de teleurstelling, door vele zaken veroorzaakt, merkelijk vermeerderd door een bijzonder soort moeilijkheden, waarvoor men meende door de wettelijke bepalingen gevrijwaard te zijn; wij bedoelen de schier overal ondervonden bezwaren bij gewensehte executie der hypotheeken. De praktijk heeft volstrekt niet aan de theorie beantwoord; langs allerlei wegen hebben daarbij belanghebbenden in Amerika gezocht de rechten der hypothecaire geldgevers te verminderen of te niet te doen. Het moet echter erkend worden dat de geldgevers alhier meermalen, door een zekere lauwheid om voor hunne belangen optekomen en daartoe zich te 
concentreeren, die moeilijkheden in de hand gewerkt hebben in stede van ze te bestrijden.

De slotsom, waartoe ons onderzoek ons brengt is, dat de opname van Amerikaansche spoorweg-fondsen in haar geheel beschouwd eene dwaling geweest is, wat aangaat het tijdstip waarop die heeft plaats gehad. Men heeft onder de impressie van verschijnselen, die geen juist beeld leverden van den werkelijken stand van zaken, zich aangesloten aan ondernemingen, die uit hun aard, hoe goed ook op zich zelve en op den duur, te naw in verband staau met de algemeene welvaart, als dat men straffeloos zich aangaande deze bedriegen kon. In zooverre als dit echter tot geen andere gevolgen had kunnen leiden, dan tot eene voorbijgaande depreciatie van gekochte aandeelen en obligatien, ware het nadeel daaruit ontstaan zeer beperkt gebleven. Maar, door de algemeene uitlureiding destijds van het spoorwegnet in Amerika was iedere deelneming in spoorwegen aldaar - in de eerste plaats in de nieuwere spoorwegen, maar ook in de ouderen wier toestand daardoor gewijzigd werd - een zich aansluiten aan die algemeene beweging van spoorweguitbreiding, die, voortgesproten uit diezelfde opvatting van verschijnselen, eene bepaalde fout is geweest. En de gevolgen van die fout zijn zooveel te ernstiger en te gevoeliger geweest, daar, geheel onder den invloed dier gunstige impressies, men niet genoegzaam acht heeft geslagen op de zwakke zijden van verschillende dier ondernemingen, die wel zonder gevaar waren, indien geen verkeerde opvatting plaats vond van den algemeenen toestand en van de daaraan vast te knoopen verwachtingen, maar die de oorsprong moesten worden van velo teleurstellingen, zoo die verwachtingen verijdeld werden, gelijk geschied is; voorts, daar tegelijkertijd men niet genoegzaam eeı gewapend oog heeft gehad voor mogelijke misleiding van de zijde van sommige ontwerpers, iets wat echter altoos moeilijk te onderkennen en te beoordeelen blijft, daar er, tot wat later gebleken is overdreven en onjuiste voorstellingen en verwachtingen te zijn geweest, aanleiding genoeg was in die onjuiste appreciatie van een aantal sociale, politieke, economische en finanecieele vraagstukken, die, dit bedenke men steeds, niet alleen hier maar allereerst in Amerika zelf bestond en aldaar geruimen tijd zoo groote overspauning veroorzaakte, waardoor ook de besten en verstandigsten zich bedriegen konden.

Tegen de mogelijkheid van eene zoodanige onjuiste appreciatie van den toestand van een land op een gegeven tijdstip zijn geen 
bulpmiddelen aan de hand te doen. Het gevaar voor zoo aanzienlijke vergissing als in dit geval, is echter niet groot; zeldzaam zal het zich voordoen dat de juiste stand van zaken door zoovele bedriegelijke verschijnselen verborgen wordt, en dan nog daarbij komt, dat latere gebeurtenissen alle medew̌rken om de gevolgen der gevaren, die in den eigelijken toestand gelegen waren, te verergeren.

Wat wij echter laatstelijk (in ons December beurs-overzicht) opmerkten ten opzichte van geldbelegging in staatsfondsen is ook hier van toepassing; het is wenschelijk dat men zich ter beoordeeling van alle aankoopen van fondsen op een minder eng standpunt plaatse dan veelal geschiedt. Er is geen zaak denkbaar, waarop de algemeene toestand van een land niet van invloed zou zijn.

Stellen wij ons op dat standpunt ter behandeling der vraag of het wenschelijk is zijne kapitalen te plaatsen in ondernemingen in Amerika, zoo meenen wij thans deze conclusie te mogen formuleeren: dat eenige hervormingen noodig zijn, eer men dit met volkomen vertrouwen en onder de gunstigst mogelijke omstandigheden zal kunnen doen. Amerika moet terugkeeren tot de speciebetalingen; door intrekking van het Staatspapierengeld en de instelling van een goed georganiseerd bankwezen, gegrond op inwisselbaarheid der billetten, moet de circulatie op den eenig deugdelijken grondslag hersteld worden. Volkomen moet gebroken worden met het protectionistisch stelsel on in stede daarvan het vrijhandel-stelsel zonder eenige beperking toegepast worden. Eene volledige zuivering moet plaats vinden van de regeerings en administratieve kringen; onkreukbare en onbetwistbare eerlijkheid moet het eerste vereischte worden voor de vervulling van alle ambtenaarsbetrekkingen, en evenzeer voor hen die geroepen worden de Unie, de afzonderlijke Staten en de Gemeenten in de vergaderzalen der wetgevende en controleerende machten te vertegenwoordigen; zoo moeten ook de noodige wettelijke hervormingen plaats vinden, bijzonder in de organisatie der rechterlijke macht, om de tegenwoordig bestaande gelegenheden en gevaren voor misbruik van macht zooveel mogelijk weg te nemen. Eindelijk moet, wat angaat de Zuidelijke Staten, aan hen, die door sociale en financicele positie het grootste belang hebben bij de orde en rust in die Staten en bij hunne welvaart, hun rechtmatig aandeel in het bestuur en hun invloed op den gang van zaken niet langer onthouden worden. Niet voor dat aan deze vier vereischten voldaan zal worden, zal 
men kunten rekenen op die volheid van ontwikkeling en bloei, die de buitengewone natuurlijke rijkdommen en voordeelen van het land recht geven te verwachten; eerst dàn zal men verzekerd zijn, dat geen stoorende invloed de natuurlijke ontwikkeling der welvaart meer zal tegenwerken.

Dat ondanks de gebreken die aan den tegenwoordigen toestand van Amerika kleven, het land toch niet meer geleden heeft dan het geval is geweest, bewijst echter een vitaliteit en rijkdom van hronnen van welvaart als zeldzaam is; en al zal men dan ook wel doen de zwakke zijden van den toestand nimmer uit het oog te verliezen, zoo bestaat er toch geen oorzaak om zich geheel te onthouden van geldplaatsingen in Amerika, zoolang de gewenschte hervormingen niet tot stand zijn gekomen. Naast vele ondervonden teleurstellingen heeft men ook in werkelijkheid alhier reeds genoegzaam de ervaring opgedaan dat, zelfs zoo als thans de zaken in Amerika staan, daar een ruim veld is voor remuneratieve plaatsing van Europeesch kapitaal.

De ondervinding heeft echter tevens geleerd, dat, wat spoorwegondernemingen aangaat, onze deelneming in den regel op eene andere wijze zal moeten plaats vinden, dan tot heden geschied is. Meerdere behoedzaamheid dan men noodig oordeelde alvorens het terrein door ervaring te kennen, het nemen van meerdere voorzorgsmatregelen voor alle eventualiteiten, zal wel als eerste voorwaarde gesteld moeten worden. De waarborgen, waarop men meende te kunnen rekenen zijn gebleken niet te bestaan of onvoldoende te zijn. Zoo heeft men ondervonden dat bij nieuwe spoorwegen, ondanks de beste vooruitzichten, de kansen van succes te wisselvallig zijn, dan dat, bij de tegenwoordige financiëele organisatie der maatschappijen, de obligatien aanstonds de noodige zekerheid aanbieden. Zoude voortaan een werkelijk in geld gestort aandeelen-kapitaal eerst bijeengebracht worden, en slechts in eene bepaalde en voldoende verhouding tot dit, uitgifte van hypotheek-obligatien plaats vinden, zoo werd aan dit euvel zeker voor een goed deel te gemoet gekomen. Ontbreken echter ten eenre de voorbeelden niet van maatschappijen, waarbij het aandeelen-kapitaal volstrekt niet op die wijze gevormd is, en waarvan toch de obligatien bleken eene zeer goede securiteit te zijn, ten andere ontbreken evenmin de bewijzen, dat daardoor nog volstrekt niet alle gevaren te boven gekomen zouden worden. Ook bij dergelijke organisatie zou nog ruimte genoeg overblijven, bij den spoorweg-aanleg, alsmede bij de exploitatie, voor onvoldoende 
besteding en aanwending van het kapitaal. Bovendien de kosten en rendementen der spoorwegen loopen te veel uiteen, dan dat men alleen uit de kennis der kapitaals-formatie een afdoend oordeel over de soliditeit der obligatien zou kunnen vormen. Zoo oefenen $b$. v. aansluitingen en verbindingen met andere spoorwegen een grooten invloed op het verkeer, en dat niet aansluitingen als aangegeven worden door kaarten, maar feitelijke aansluitingen, het gevolg van overeenkomsten en kontrakten, waaromtrent uit kaarten niets blijken kan, en waarvan het nut of de behoefte voor den niet volkomen ingewijde dikwijls eerst uit de verkregen wordende resultaten gekend kan worden.

Men heeft geopperd dat, ter gemoetkoming aan deze en dergelijke bezwaren, aan obligatiehouders. stem gegeven moest worden in de keuze van directeuren, opdat zij invloed zouden kunnen uitoefenen op den gang van zaken. Zoo is ook de wenschelijkheid betoogd, dat de macht van obligatiehouders om eventueel tot executie van hun onderpand over te gaan uitgebreid worde, en dat de mogelijkheid om dergelijken maatregel te verlangen beter binnen hun bereik zoude worden gebracht, door dien afhankelijk te maken van minder algemeene zamenwerking, dan tot nog toe veelal een vereischte is; ook dat hun meer macht gegeven worde, om tot eene eenvoudige inbezitname van den spoorweg over te gaan zonder voorafgaande gerechtelijke executie. In vele opzichten zouden dergelijke bepalingen zeer goed zijn, maar in de positie waarin de niet-Amerikaansche obligatie-houders, behoudens mogelijk enkele uitzonderingen, thans verkeeren, zouden zij daardoor al zeer weinig gebaat worden. Iedere overbrenging van macht in het bestuur of de contrôle der zalien, of maar van invloed daarop, naar den Europeeschen obligatie-houder zoude de tegenwoordige positie van dezen allicht integendeel slechts moeilijker maken. Of zijn, niet vele ondervonden teleurstellingen het gevolg daarvan, dat men ter beoordeeling van zaken en toestanden hier de noodige gegevens miste, en onmogelijk kon doordringen tot de kennis der bijzonderheden, waarin het ten slotte bleek dat het zwaartepunt gelegen was? Is niet, vooral waar het de questie gold tot executie van hypotheek over te gaan, het bezwaar waarop men stuitte herhaaldelijk gebleken daarin te bestaan, dat men dan zelf de zaak in handen moest nemen, waartoe de mogelijkheid ontbrak?

$\mathrm{Om}$ aan die bezwaren te gemoet te komen is het noodig, dat, ten eerste tusschen de verschillende geldschieters alhier onderling, ten andere tusschen hen en de onderneming zelve in Amerika een 
veel nanwere band besta, dan tegenwoordig als regel het g'eva is. Nederlandsch-Amerikaansche of Amerikaansch-Nederlandsche huizen zullen de verbinding moeten daarstellen tusschen de geldgevers alhier en de geldnemers, het bestuur der zaak aldaar; en, indien al bij uitzondering in enkele groote zaken, waarvan bovendien de overgroote meerderheid der daarbij belanghebbenden toch in Amerika zelf zijn, de Nederlandsche geldschieters eenvoudig obligatie-houders zelfs aandeelhouders zullen kunnen zijn, zoo zal de regel moeten wezen, dat van den aanvang af, hetzij der zaak of van de Nederlandsche participatie daarin, dit geschiede door volledige aaneensluiting der belanghebbenden, terwijl die dan tevens ter plaatse door huizen als bedoeld vertegenwoordigd zullen moeten zịjn, en door die vertegenwoordiging de voortdurende waarneming hunner belangen verzekerd moet worden, waartoe die vertegenwoordiging een volkomen goed georganiseerde en krachtige zal moeten zijn. In verdere bijzonderheden dienaangaande te trelen ligt niet in onze bedoeling, slechts merken wij op dat de deelneming in spoorwegleeningen zal moeten geschieden door middel van een administratiekantoor, dat als houder der origineele stukken de macht en kracht zal hebben, om voortdurend te controleeren en zoo noodig te handelen, en waardoor een blijvende zakelijke band tusschen partijen gevormd zal worden.

Wij miskennen volstrekt niet wat reeds op dezen weg is uitgericht, maar vinden veeleer juist daarin eene aanwijzing, dat veel meer die weg betreden, veel meer die richting opgegaan moet worden. Zoo hebben - om enkele voorbeelden te noemen de Heeren Hope \& Co. de door ons bedoelde positie ingenomen, in zake de leeningen der Louisiana-Bank. Zoo was het administratiekantoor onder directie van de Heeren ten Have \& van Essen c. s. een ijverig vertegenwoordiger van de geintereseerden bij den ChicagoNorth Western spoorweg, legale vertegenwoordiger en in staat tot handelen is het echter alleen voor de aandeelhouders. Zoo is voor de aandeelhouders in de Mlinois Spoorweg-Mij laatstelijk het voordeel van eene dergelijke organisatie gebleken. Zoo heeft het MissouriKansas-Texas Comité; dat op een gegeven oogenblik en voor een speciaal geval als administratie-kantoor voor de obligatie-houders fungeerde, het nut van aaneensluiting en krachtige vertegenwoordiging bewezen. Maar, om bij dit laatste voorbeeld te blijven, is het niet waarschijnlijk dat vele moeilijkheden en verliezen in die zaak voorkomen zouden zijn, indien van den aanvang af dergelijke vertegenwoordiging van de Nederlandsche obligatie-houders, goed georgani- 
seerd en met bepaalde macht bekleed, naast de Directie had gestaan. Zijn er niet andere gevallen die aantoonen, dat, wanneer dergelijke vertegenwoordiging niet van den aanvang af bestaan heeft, ze op het oogenblik, dat ze absoluut noodig werd, niet tot stand te brengen was? Tegen de bestaande verschillende administratie-kantoren is overigens in het algemeen dit aantevoeren, dat ze veelmeer beoogen de administratie der financiëele resultaten van de deelneming in eene of in meerdere zaken, dan de volledige vertegenwoordiging der belangen in die zaken, waartoe ze dan ook niet opgericht noch ingericht werden.

Door doeltreffende aaneensluiting en vertegenwoordiging zullen de Nederlandsche kapitalisten ook hunne werkkring in Amerika op winstgevende wijze kunnen uitbreiden. Niet tot de rol van obligatie-houder of aandeelhouder in bestaande of in aanbouw zijnde spoorwegen zal men zich dan behoeven te bepalen, maar ook aan de daarstelling van nieuwe wegen en in de daaraan verbonden voordeelen zou men, bij terugkeer van daartoe gunstige tijden, zoodoende kunnen deelnemen. Natuurlijk dat wel niet voor iedere geldplaatsing zoo iets wenschelijk zal zijn, zelfs het eenvoudig aandeelen-bezit zal door menigeen vermeden moeten worden. Uit den aard der zaak zullen aan aandeelen altoos meer risico's verbonden zijn dan aan obligatiën; een spoorweg is geen zaak die gisteren en morgen altoos dezelfde winsten geeft, door tijdsomstandigheden en verschillende gebeurtenissen zal het rendement voor den aandeelhouder min of meer geïnflucueerd worden. Dit wordt thans weder bewezen door de geschiedenis van den Illinoisspoorweg, ofschoon zeker geen aandeelhouder zich over zijn aandeelenbezit in deze maatschappij te beklagen heeft, dan zij die, bedoelde waarheid vergetende, koopers zijn geworden toen de Aandeelen onder den invloed van hooge dividenden opgedreven werden (door henzelven) op een prijs, alleen gemotiveerd indien die dividenden voor geen vermindering vatbaar waren geweest. Bij aandeelen zal men altoos tegenover de kans van betrekkelijk groote winsten ook die van min gunstige resultaten in het oog moeten houden, en allermeest bij de onderneming van nieuwe zaken. Maar onze voorouders zijn niet groot en rijk geworden door het vermijlen van alle risico's; niet van de tijden, toen zij met hun kapitalen zich aan nieuwe ondernemingen durfden te wagen, dagteekent ons verval, maar slechts van den tijd, toen die ondernemingsgeest door het beursspel vervangen werd.

Dan, ook voor eenvoudige geldbelegging is het terrein in Amerika 
niet tot de deelneming in spoorweg-leeningen beperkt. Geldbelegging in hypotheeken op vast goed, gebouwde en ongebouwde eigendommen, geeft wellicht even goede rente met nog minder risico, en zoude, door de inrichting van een speciale administratie in den geest als wij bedoelen, ook onder het bereik der Nederlandsche kapitalisten gebracht kunnen worden.

Bekend is het ook, dat onder de leeningen der bijzondere Staten van Amerika er gevonden worden, die geen mindere waarborgen aanbieden dan die der Ver. Staten. Vooral ook onder de leeningen der steden, veelal aangegaan tot het daarstellen van werken van openbaar nut, zijn er velen die door zeer groote securiteit aanbevelenswaardig zijn. Maar ook te dien opzichte is bemiddeling tusschen geldgevers en geldnemers noodig; tot appreciatie van al dergelijke fondsen is niet alleen groote plaatskennis, maar ook de kennis van een aantal uiteenloopende wettelijke bepalingen een onmisbaar vereischte, en ook bij die fondsen dienen de geldgevers in eene blijvende vertegenwoordiging, al behoeft die hier niet zoo vormelijk te zijn als in spoorwegzaken, waarborgen te vinden voor een voortdurend werkend toezicht over hunne belangen.

Hoezeer eindelijk door het meer en meer tot stand komen van dergelijke nauwere banden tusschen onze kapitalisten en hunne ondernemingen of geldnemers, in het algemeen de relatie tusschen onze geldmarkt en Amerika verbeterd zou worden, hoezeer daardoor telkens nieuwe gelegenheden tot vruchtbare besteding van kapitaals en arbeidskrachten zouden ontstaan, en daardoor ook eene zoo wenschelijk bevonden meer ingrijpende kennis van zaken en omstandigheden bevorderd zou worden, behoeft geen betoog.

Amsterdam, Januarij 1877.

Naschrift. Verschillende gebeurtenissen, als de beslissing betreffende de verkiezing van den nieuwen president der Ver. Staten, de uitspraak van het Hoogste Gerechtshof te Washington aangaande de rechten der Staten tot bepaling der spoorwegtarieven, het Denver Pacific spoorweg incident, enz., zouden ons heden eigenlijk noodzaken onze beschouwingen voort te zetten. Tijd en ruimte ontbreken evenwel om deze onderwerpen thans naar eisch te behandelen. Wij moeten dit dus uitstellen tot ons eerstvolgend $3 / \mathrm{m}$. beursoverzicht.

20 Muar/.

Econ. 1877.

BIJLAGE. 


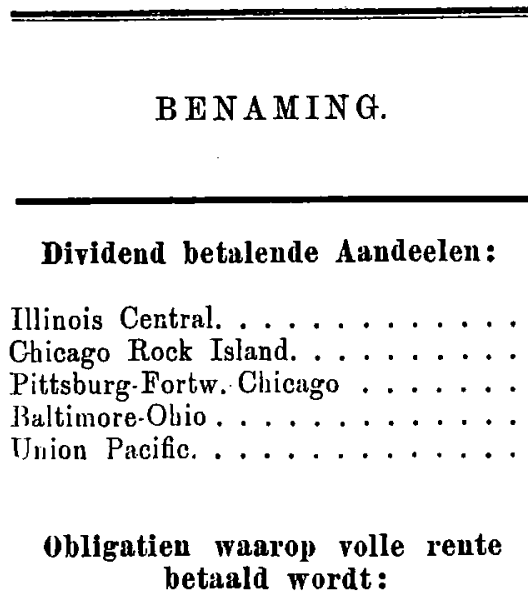

Itlinois Redemption. .....6 pCt. Clic. \& N.-W. Madison . . . . 7" "Menomenee......7" "Winona St. Peter ... . 7" "Northwestern Union . . . 7 " Jowa Midland . . . . . 8 "Geconsolideerde. . . . . . 7

Centraal Pacific.......6,

Californie \& Oregon . . . . . 6 " San Joaquin. ........ 6 , Union Pacific........6, 6 , Atl. \& G. Western Oliio. . . . 7 Chicago \& S. Western . . . . .7 Denver Pacific ....... 7 , Denver Boulder. . . . . . . . 7 " South Miss. Pacific. . . . . . 6 North Missouri ....... 7 Denver Rio Grande ..... . 7 Atch. Topeka Santafe. . . . . 7 Milwaukee St. Paul Goud . . . 7 " " Curr. ...7" Diverse spoorwegen. . . . . .

\section{Obligatien waarop een deel der rente wordt betaald:}

Clevelund Mt. Vernon \& . . . . . Columbus Ext . . . . . . 3 $3 \frac{1}{2}$ pCt. Marietta Pittsburg......... Kansas Pacific....... $3 \frac{1}{2}$ pCt. Oregon Californie...... $2 \frac{1}{2}$ "

\begin{tabular}{|c|c|}
\hline $\begin{array}{c}\text { DATUM } \\
\text { van Emissie of } \\
\text { Invoer. }\end{array}$ & $\begin{array}{c}\text { TOTAAL } \\
\text { bedrag der } \\
\text { Uitgifte. }\end{array}$ \\
\hline
\end{tabular}

GERAA UD

bezit in

November $18 \%$

\section{April 1871}

Junij 1871

December 1871

Junij 1872

November 1870

September 1873

$1869-70$

Mei 1871

Januarij 1872

Julij 1871

$1865-67$

Maart 1870

Februarij 1870

Junij '7l/Oct. '72

Augustus 1869

Jan.-Mrt. 1870

November 1870

Junij 1872

Maart 1872

Februarij 1872

Julij 1870

Januarij 1872

Januarij 1872

Januarij 1870

Januarij 1872
Dollars.

29.000 .000

25.000 .000

19.714 .000

13.143 .000

36.745 .000

2.500000

3.150 .000

2.700 .000

4.375 .000

3.500 .000

1350.000

9.758 .000

25.883 .000

6.000 .000

6.080 .000

27.236 .000

4.000 .000

5.000 .000

2.500 .000

o50000

7.188 .500

6.000 .000

2.750 .000

2.700 .000

4.000 .000

1.080 .000

1.300000

1.000 .000

1.500 .000

6.500 .000

10.950 .000
Dollars.

8.000000

1.000 .0011

2.200 .000

300.0011

500.000

12.000 .000

2.500 .000

3.150 .000

2.700 .000

4.375 .000

3.500 .000

700.000

1.000 .000

9.000 .000

4.000 .000

4.000 .000

6.000 .000

2.000 .000

3.000 .000

1.500 .000

500.000

300.000

500.000

1.500 .000

300.000

700.000

500.000

500.000

52.225 .000

$\begin{array}{r}\hline \\ 1.300 .000 \\ 900.000 \\ 1.100 .000 \\ 700.000 \\ 1.200 .000 \\ \hline 5.200 .000 \\ \hline\end{array}$

† Nil aftrek ran stoek-diidend,

* De rollar $f 2,40$. 


\section{fondsen in Nederland.}

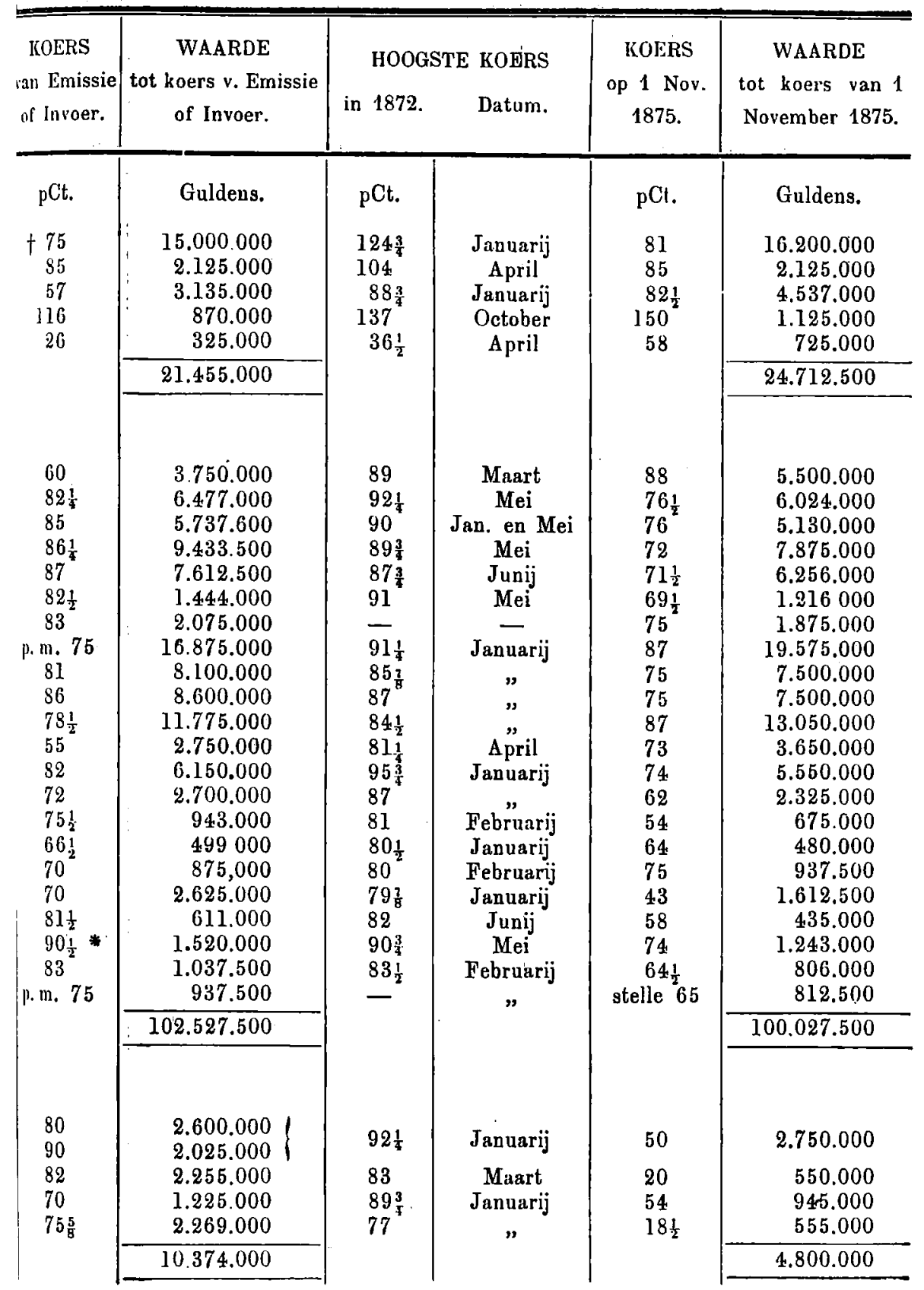




\begin{tabular}{|c|c|c|c|}
\hline BENAMING. & $\begin{array}{c}\text { DATUM } \\
\text { van Emissie of } \\
\text { Invoer. }\end{array}$ & $\begin{array}{c}\text { TO'IAAL } \\
\text { bedrag der } \\
\text { Uitgifte. }\end{array}$ & $\begin{array}{c}\text { GERAAMD } \\
\text { bezit in } \\
\text { November } 187\end{array}$ \\
\hline $\begin{array}{c}\text { Obligatien warrop rentebetaling } \\
\text { gestaakt is: }\end{array}$ & & Dollars. & Dollars. \\
\hline Paul \& Pacific le Sectie . . . . . . & Maart 1866 & 1.200 .000 & 1.200 .000 \\
\hline $\quad$ Gecons. . . . . & Augustus 1866 & 780000 & 780.000 \\
\hline 2e Sectie & - & 3.000000 & 3.000 .000 \\
\hline 1869 . & Januarij 1869 & 6.000 .000 & 6.000 .000 \\
\hline St. Vincent Brainard & Julij 1871 & 15.000 .000 & 10.000 .000 \\
\hline Atl. \& Mississippi \& Ohio & October 1871 & 6.000 .000 & 3.000 .000 \\
\hline Miss Kansas Texas \& U. P. S. B. . . & Junij ' $69 /$ Mei ${ }^{\prime} 71$ & 19.500 .000 & 12.500 .000 \\
\hline Gilman Springfield. . . . . . & Januarij 1872 & 2.000 .000 & 600.000 \\
\hline Toledo Peoria \& Warsaw. . . . . . . & Mei 1871 & 1.500 .000 & 700.000 \\
\hline Chesapeake \& Obio . & Januarij 1872 & 15.000 .000 & 250.000 \\
\hline Porthnson \& Chicago & Febr.'70/Mrt. '7l & 1.700 .000 & 800.000 \\
\hline St. Louis \& South Eastern . . . . . & Mrt.'70/April '7l & 2200.000 & 1.000 .000 \\
\hline Rockford, Rock Isl. \& S. L. . . . . & April 1869 & 9.000000 & 600.000 \\
\hline West-Wisconsin . . . . . . . & Aug. '68/Mrt. '70 & 4.000 .000 & 1.000 .000 \\
\hline Californie Extention. . . & September 1869 & 3.500 .000 & 500.000 \\
\hline Atchison Branch. . & April 1872 & 1.000 .000 & 600.000 \\
\hline Florida Sedar Key. & Julij $187 \mathrm{I}$ & 2.300 & 500.000 \\
\hline Paducah Memphis . & April 1872 & 2.5 & 1.500 .000 \\
\hline Elisabeth town \& Paducal ...... & Mei 1871 & 3.000 & 2.500 .000 \\
\hline Port Royal. & April 1870 & 2.700 .000 & 100.000 \\
\hline Cairo \& St. Louis. & Februarij 1872 & 2.500 .000 & 1.800 .000 \\
\hline Desmoines Valley & Maurt 1870 & 2.200 .000 & 800.000 \\
\hline Alabama \& Chattanooga. & Augustus 1869 & 4.700 .000 & 250.000 \\
\hline Arkausas Central. & Maart 1872 & 1.200 .000 & 150.000 \\
\hline Diverse spoorwegen & - & - & 500.000 \\
\hline 8 pCts. Staai Florida. & December 1870 & 3.200 .000 & 2.000 .000 \\
\hline Maxwell Maatschappij Leen. 187 & Junij 1870 & 3.500000 & 3.000 .000 \\
\hline " $1872 \ldots$ & $\begin{array}{c}\text { Deceniber } 1872 \\
1873\end{array}$ & $\begin{array}{r}1.125000 \\
250000\end{array}$ & $\begin{array}{l}750.000 \\
250.000\end{array}$ \\
\hline \multirow[t]{2}{*}{ Costilla Estate Maatschappij ..... } & \multirow[t]{3}{*}{ December 1870} & \multirow[t]{3}{*}{2.500000} & 2.500 .000 \\
\hline & & & 59.130 .000 \\
\hline \multicolumn{2}{|l|}{$\begin{array}{l}\text { Aandeelen met meer of minder } \\
\text { voornitzicht op dividend: }\end{array}$} & & \\
\hline Chicago North-Western & 1869 & 21.494 .000 & 8.000 .000 \\
\hline kee St. Paul & Maart 187 & 12.27 & 1.100 .000 \\
\hline and Indranapolis & Januarij 187I & 15.000 & 550.000 \\
\hline \multirow[t]{2}{*}{ Michigan Central ......... } & $1869-1870$ & 18.738 .000 & 500,000 \\
\hline & \multirow{5}{*}{$\begin{array}{l}1869 \\
1871\end{array}$} & \multirow{5}{*}{$\begin{array}{r}78.000 .000 \\
5.000 .000\end{array}$} & 10.150 .000 \\
\hline Bloot speculative Aaudeelen: & & & \\
\hline Eric spoorweg . . . . . . . & & & 4.000 .000 \\
\hline \multirow[t]{2}{*}{ Maxwell Maritschappij........ } & & & 500.000 \\
\hline & & & 4.500 .000 \\
\hline
\end{tabular}

\footnotetext{
* De dullar à $f 2.40$.
} 


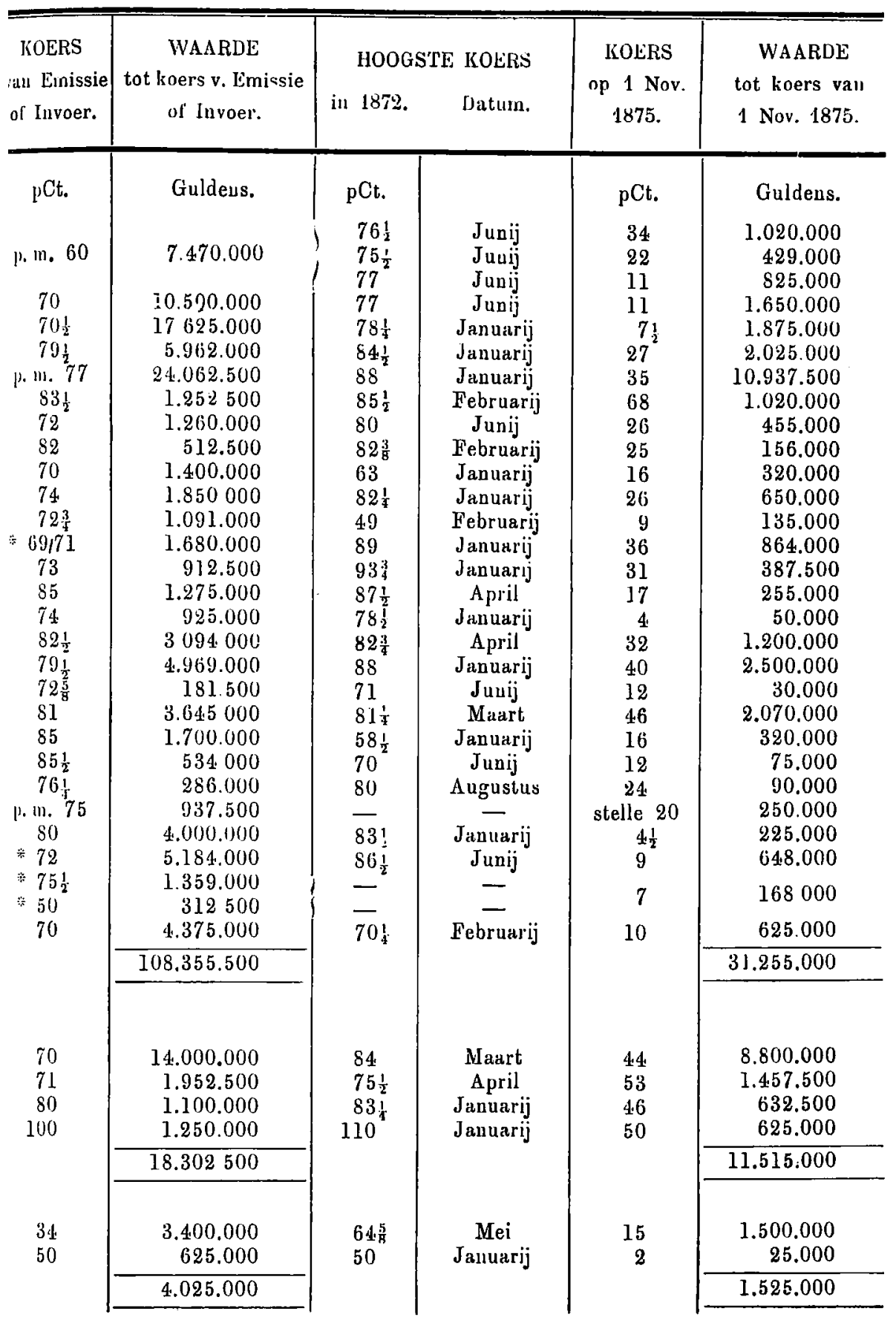




\section{R E C A P I T U L A T I E.}

Geraamd bezit

W A A R D E.

op 1 Nov. 1875.

nom. bedrag. tot oorspr. koers. 1 Nov. 1875 .

Dividrud betalende Aan-

Dollars.

Guldens.

Guldens.

declen . . . . .

Obligatien waarop rente betaald wordt . . .

Obligatien wạarop rente ten deele betaald wordt

Obligatien waarop rentebetaling gestaakt . Aundeelen met $\min$ of meer kalls op dividend Bloot speculatieve Aan-

\begin{tabular}{rrr}
$12,000,000$ & $21,455,000$ & $24,712,500$ \\
$52,225,000$ & $102,527,500$ & $100,027,500$ \\
$5,200,000$ & $10,374,000$ & $4,800,000$ \\
$59,130,000$ & $108,355,500$ & $31,255,000$ \\
$10,150,000$ & $18,302,500$ & $11,515,000$ \\
$4,500,000$ & $4,025,000$ & $1,525,000$ \\
\hline $143,205,000$ & $\frac{265,039,500}{173,835,000}$ \\
\hline
\end{tabular}

declen . . . . . $\frac{4,500,000}{143,205,000} \quad \frac{4,025,000}{265,039,500}-\frac{1,525,000}{173,835,000}$ 